\title{
Arte y cultura masónica en el México barroco
}

\section{Art and Masonic culture in the Baroque Mexico}

\author{
Martha Fernández \\ Investigadora del Instituto de Investigaciones Estéticas de la Universidad Nacional Autónoma de México. \\ Doctora en Historia del Arte. Correo: electrónicos: marfer@unam.mx y marafermx@yahoo.com
}

DOI: http://dx.doi.org/10.15517/rehmlac.v8i2.18014

Fecha de recibido: 25 de octubre de 2015 - Fecha de aceptación: 12 de octubre de 2016

\author{
Palabras clave \\ Barroco; iconografía; cultura masónica
}

Key words

Baroque; iconography; Masonic culture

\begin{abstract}
Resumen
A pesar de su importancia, la masonería en el arte del México barroco es un tema ausente en la historiografía, no obstante, existen elementos suficientes para pensar que pese a todos los obstáculos que enfrentaron, artistas y sociedad pudieron vincularse con la cultura masónica desde finales del siglo XVII y principios del siglo XVIII. Conceptos como el del Gran Arquitecto del Universo, la representación de los Santos Coronados, la presencia de símbolos iconográficos como la escuadra, el compás y la plomada, así como el retrato de un arquitecto novohispano como maestro masón, nos llevan a considerar esa posibilidad. Todo ello, dentro de un contexto artístico y social en el que deben tomarse en cuenta la crisis gremial y la existencia de una cofradía titulada de Nuestra Señora de los Gozos y Santos Arquitectos. En este artículo presento avances de una investigación más amplia que desarrollo en torno a ese tema.
\end{abstract}

\begin{abstract}
Despite its importance, Freemasonry in the art of the Baroque Mexico is absent in historiography, though there are enough elements to believe that despite all the obstacles faced, developments in art and society can be linked to Masonic culture since the end of the seventeenth century and early eighteenth century. Masonic concepts such as the Great architect of the universe, the representation of the Saints crowned, the presence of iconographic symbols such as the square, compass and Plumb, as well as the portrait of a novohispano architect as a master mason, lead us to explore that possibility. All of this considered within a social and artistic context must take into account the trade crisis and the existence of a titled Brotherhood of our Lady of joys and Santos architects. In this article I present advancements of a broader investigation that I'm developing on this important issue.
\end{abstract}

\section{Preámbulo}

La existencia de la masonería en la época virreinal de México es uno de los temas mayormente ignorados por la historiografía. Se ha estudiado, por supuesto, su presencia cuando comenzaba el proceso de Independencia, a finales del siglo XVIII y principios del 
siglo XIX, vinculado a la Ilustración y, desde luego, a la Revolución Francesa ${ }^{1}$. Sin embargo, nada se ha comentado acerca de los posibles vínculos que pudo tener la sociedad novohispana y sus artistas desde finales del siglo XVII. El asunto es complejo, pero tiene que ver con el desarrollo de lo que puede denominarse como "Ilustración novohispana", que comienza a esbozarse en la época de Carlos II y se deja ver de manera abierta, a raíz de las Reformas Borbónicas, ya en el siglo XVIII; todo lo cual constituye el origen del proceso que a la postre dio lugar a la Independencia nacional ${ }^{2}$.

Desde luego, no se puede ignorar la persecución que sufrió la masonería en los reinos de España, muy especialmente a partir de la bula In eminenti, que el papa Clemente XII, emitió el 28 de abril de 1738, prohibiendo, bajo pena de excomunión, "la compañía y conventículos de los Liberi Muratori, o sea de Fancs Massons”, seguida por las órdenes del Inquisidor Mayor de España, el arzobispo Andrés de Orbe y Larréategui, quien, "según la práctica y costumbre de España”, el mismo año de 1738 exigió “en todos los Reinos y Señoríos de Su Majestad" el cumplimiento del contenido de dicha bula, en nombre del Santo Oficio de la Inquisición”. Poco se habrán atendido esas disposiciones, cuando el 6 de marzo de 1751, el papa Benedicto XIV, tuvo que expedir otra bula similar a la de su antecesor, ${ }^{3}$ a la que siguió el Real Decreto que Fernando VI expidió el Aranjuez el 2 de julio de 1751, prohibiendo también las Congregaciones de los Francmasones. No solo eso, José Antonio Ferrer Benemeli publicó una serie sanciones impuestas por el Santo Tribunal de la Inquisición de México, en contra de francmasones, durante la segunda mitad del siglo XVIII ${ }^{4}$.

Sin embargo, la existencia de esas prohibiciones, nos deja ver la presencia de lo que se prohibía, es decir, de la masonería anterior a 1738. Asimismo, esas contravenciones no se limitaron a la España de la Península Ibérica, sino que fueron extensivas a "todos los Reinos y Señoríos de Su Majestad”, lo que lógicamente comprendería a los virreinatos de América. Esto es, que no podemos soslayar la posibilidad de que en la América virreinal se desarrollara también un acercamiento a la cultura masónica antes de las prohibiciones de 1738. Al mismo tiempo que esas tempranas prohibiciones no tuvieron el efecto esperado, pues de otra manera, Fernando VI no hubiera tenido necesidad de expedir el Real Decreto, prohibiendo nuevamente las cofradías masónicas. A ello, se agrega el hecho de que, como

\footnotetext{
${ }^{1}$ María Eugenia Vázquez Semadeni, "La imagen pública de la masonería en Nueva España, 1761-1821", Relaciones XXXIII, no. 125 (2011 [citado el 30 de noviembre de 2015]): disponible en http://www.revistarelaciones.com/files/revistas/125/pdf/07mariaEugeniaVazquez.pdf

${ }^{2}$ Martha Fernández, "El arte: de la Ilustración novohispana a la Ilustración en México", en El arte en tiempos del cambio 1810-1910-2010 (CDMX: UNAM, IIE, 2012), 23-54.

${ }^{3}$ Rogelio Aragón Juárez, "Contra la Iglesia y el Estado: Masonería e Inquisición en Nueva España, 17601820" (Tesis de Licenciatura en Historia, Universidad Instituto Helénico, 2006), 33.

${ }^{4}$ José Antonio Ferrer Benemeli, La masonería española en el siglo XVIII (Madrid: Siglo XXI de España Editores, 1974), 72-80, 160, 216-218, 293-301, 318-326. Véase también: Aragón Juárez, ““CContra la Iglesia y el Estado", 50-88.
} 
lo deja ver Rogelio Aragón Juárez en su tesis titulada: "Contra la Iglesia y el Estado: Masonería e Inquisición en Nueva España. 1760-1820”, hubo masones en México y la Inquisición novohispana fue bastante descuidada en relación con ellos, incluso con los confesos. $^{5}$

Por otra parte, en el libro titulado La Ilustración Iniciada, Nicola Lococo, comenta que existen indicios de la existencia de la masonería incluso no operativa desde el "mismísimo inicio del siglo XVII", concretamente en Francia, Italia e Inglaterra. Por supuesto, también acepta que esta hipótesis, así como las pruebas que la sustentan, han sido abiertamente discutidas por los expertos en uno y otro sentido, pero desde el punto de vista histórico, no dejan de ser interesantes y llamativos algunos de sus testimonios que presenta como, por ejemplo, el que William Schaw (1550-1602), en su calidad de "director general de los Maestros Masones", haya publicado "unos estatutos con la aquiescencia general" en el año de 1598. Asimismo, el que, a Iñigo Jones, Señor de Saint Clair se le nombrara "Maestro" el año de 1607 y que "a imitación de las academias italianas", organizara "Logias donde era más sencillo acceder por cuanto tenían otras artes y sensibilidades"

Respecto a España, en realidad los estudios sobre masonería, comienzan con la fundación de la primera logia propiamente especulativa. De acuerdo con José Antonio Ferrer Benemeli, ese suceso tuvo lugar "el 15 de febrero de 1728, en el Hotel francés de las Tres Flores de Lys, que se encontraba en la calle ancha de San Bernardo, y recibió el número 50 del registro oficial de Londres"7. Aunque ésta desapareció el año de 1768, no deja de ser importante como un testimonio que pudo haber tenido algún impacto en la Nueva España. En Estados Unidos, la primera logia de esa naturaleza se fundó el año de 1733. John K. Yung y Barb Karg, explican que recibió el nombre de Gran Logia de San Juan y fue establecida en Boston, por el inglés Harry Price, "a quien luego se conocería como el padre de la masonería norteamericana"

De todas maneras, considero posible tomar en cuenta que, si bien la existencia de una masonería especulativa se inicia en España hasta el siglo XVIII, no quiere decir que no se hubiera iniciado antes su proceso de gestación. Por otra parte, antes de la fundación de las Academias de Arte impulsadas por los Borbones, los artistas o artesanos, trabajaban en gremios, a la manera de los masones operativos de la época medieval. Consideremos que, si Lococo habla de una masonería operativa-especulativa en la Italia del siglo XVII, a pesar de que ya en el siglo XVI existió una Academia de Arte auspiciada por Lorenzo de Medici,

\footnotetext{
5 Aragón Juárez, "Contra la Iglesia y el Estado", 55-57.

${ }^{6}$ Nicola Lococo, La Ilustración Iniciada (España: Masónica.es, Ediciones del Arte Real, 2016), 19-21. Véase también: Jan A. M. Snoek y Henrik Bogdan, “The History of Freemasonry” en Handbook of Freemasonry (Leiden: Brill, 2014), 13-27, entre otros artículos sobre el origen de la masonería en Inglaterra y Escocia.

${ }^{7}$ Ferrer Benemeli, La masonería española (Madrid: Ediciones Istmo, 1996), 11.

${ }^{8}$ John K. Yung y Barb Karg, El gran libro de la masonería, trad. Lilia Guerrero (Bogotá: Panamericana Editorial, 2011), 41-42.
} 
no existe razón para no pensar que en España -que no tuvo Academias sino hasta el siglo XVIII- ocurriera lo mismo.

La Nueva España no debió de estar ajena a ninguno de esos procesos históricos y artísticos. De la Metrópoli llegaban tanto virreyes y nobles, como artistas y libros que de alguna manera debieron contribuir para el nacimiento de la masonería especulativa durante el siglo XVIII (como se reconoce en diversos estudios) pero cuyo proceso igualmente debió de iniciar mucho antes. Desde mi punto de vista, existen indicios -solo indicios- históricos, artísticos e iconográficos, de la posible presencia de un acercamiento a la cultura masónica, por lo menos desde el siglo XVII. Incluso, considero que puede ser factible pensar que pudo haber existido alguna especie de agrupación de esa índole que dejó varios rastros de existencia, principalmente en las obras de arte; incipiente antecedente de las logias masónicas, establecidas como tales, a principios del siglo XIX.

Conviene, asimismo, recordar, que Libny Ventura Lara identificó símbolos relacionados con la masonería en la fachada salomónica de la iglesia de San Miguel Colohete de Honduras y edificada en el siglo XVII. Entre las piezas que se encontraban en la portada, destacan la escuadra y el compás, así como el triángulo equilátero, "símbolos masónicos universalmente conocidos, representados entre la decoración fitomorfa de la fachada de estuco de bajo relieve", como afirma Ventura Lara. Igualmente, en la ermita de La Campa, de la misma jurisdicción, se encuentra el "ojo de Dios" inscrito en un triángulo y con su debido resplandor ${ }^{9}$. Si esto sucedió en una zona relativamente marginal de la entonces Capitanía General de Guatemala, no parece lógico pensar que en centro de la Nueva España no se presentara ese mismo acercamiento a la cultura masónica.

Es preciso aclarar que desde finales del siglo XVII y durante el siglo XVIII, época a la que me refiero en este artículo, se produjo el desarrollo de la cultura barroca de la Nueva España, que se considera que fue la que la dotó de identidad propia y que, por lo tanto, vendría a ser la de la consolidación de la conciencia criolla. Aunque, desde luego, no se puede negar que, en la posible aproximación a la cultura masónica, debió contribuir también la influencia de la Ilustración europea, que dio lugar la "Ilustración novohispana", así como la formación de sociedades masónicas en España y en los Estados Unidos.

Con "cultura masónica", me refiero al establecimiento no de una logia como tal, sino de agrupaciones que pudieron adoptar algunos principios de la masonería operativa para dar cohesión, identidad y consciencia de grupo a los artesanos de la Nueva España, presionados por las Reformas Borbónicas. Conciencia que implicaba el reconocimiento de sus oficios como Artes Liberales. Sin que esto fuera óbice para que la propia sociedad novohispana, que ya tenía una identidad propia, también los acogiera como parte de su

\footnotetext{
${ }^{9}$ Libny Rodrigo Ventura Lara: "El templo de Colohete (Honduras) y su significado simbólico", REHMLAC 6, no. 1 (mayo-diciembre 2014 [citado el 30 de noviembre de 2015]): disponible en http://revistas.ucr.ac.cr/index.php/rehmlac/article/view/15228/14527. De acuerdo con el autor, algunos de los signos masónicos de la portada de Colohete han sido retirados por la Iglesia católica.
} 
reafirmación como nación, no independiente de la corona española todavía, pero sí diferenciada de la metrópoli. Un fenómeno más dentro del complejo mundo cultural, filosófico y artístico de la "Ilustración novohispana". Cabe entonces preguntarse: ¿esto sería parte del proceso de gestión de una masonería especulativa en la Nueva España?

Tal vez por el carácter secretista de la masonería, no existe información concreta sobre este aspecto en las crónicas y documentación de la época, de manera que es necesario leer entrelíneas, analizar con cuidado las manifestaciones artísticas, vislumbrar signos iconográficos y aventurarse a llevar a cabo interpretaciones que incluso pueden llegar a calificarse como temerarias. No obstante, la importancia del tema, hace que el riesgo merezca la pena, por lo que en este artículo presento algunas de las primeras piezas que he reunido, para desvelar el enigma que representa el tema de la masonería en el México barroco; los primeros fragmentos de una investigación amplia que estoy apenas comenzando a esbozar.

Los indicios a los que me he referido en párrafos anteriores son los siguientes: la manera en que se reorganizaron los gremios de pintores y arquitectos a partir de la crisis gremial; la aplicación de concepto de El Gran Arquitecto de Universo, que bien pudo ser tomado del que se tuvo en la Época Medieval. La presencia devocional de los "Santos Architectos", que parece que pudieron vincularse con los Santos Coronados. Algunos de los elementos arquitectónicos que emplearon en las reconstrucciones hipotéticas del Templo de Salomón, como las llamadas columnas salomónicas de diversas tipologías, así como la representación de la Tienda cósmica que quizá (solo quizá) pueda relacionarse con la tienda del maestro masón. Elementos iconográficos como el Ojo de Dios o el Ojo que todo lo ve; los instrumentos de trabajo de los arquitectos; espadas flamígeras, cadenas y águilas bicéfalas, así como el retrato de un arquitecto con la escuadra y el compás.

Desde luego, es necesario tomar en cuenta que todos estos indicios tienen origen en muy diversas culturas y tradiciones, pero fueron retomados por la masonería, tanto operativa como especulativa y por ello me parecen importantes fuentes de información para fundamentar la idea de un acercamiento de la Nueva España a la cultura masónica.

\section{Crisis y reorganización de los gremios}

Durante los siglos XVI y XVII, los artesanos de todas las ramas fueron organizados en gremios, agrupaciones que tuvieron como principal objetivo la protección de sus individuos y el adelanto y perfección de sus productos. Aunque de alguna manera estuvieron sujetos al municipio, mantuvieron su independencia respecto a su organización interna, es así que todos participaron de un escalafón común de aprendices, oficiales y maestros; entre éstos últimos, se elegían a los veedores que eran los encargados de velar por el cumplimiento de ordenanzas y reglamentos afines. 
En el caso de los arquitectos, aunque es de suponerse que cada ciudad capital tuvo sus propios ordenamientos, solamente se conocen los de las ciudades de México y Puebla. Las primeras ordenanzas fueron expedidas precisamente en Puebla, las cuales se presentaron al Cabildo de la Ciudad el 18 de julio de 1570; fueron confirmadas por el virrey Martín Enríquez de Almanza (1568-1580) y promulgadas el mes de octubre del mismo año ${ }^{10}$. Este reglamento comprendía el trabajo de albañiles y carpinteros de la región, lo que deja ver que en ese caso los practicantes de ambos oficios estaban en el mismo gremio.

Por su parte, las Ordenanzas de Albañilería de la ciudad de México, fueron expedidas por el Cabildo, Justicia y Regimiento, hasta el 27 de mayo de 1599 y confirmadas por el virrey Gaspar de Zúñiga y Acevedo, conde de Monterrey (1595-1603), el 30 de agosto del mismo año. En este caso, la reglamentación comprendía solamente a los albañiles, arquitectos y canteros ${ }^{11}$.

Pese a los defectos que tenían y los problemas que provocaron esas ordenanzas, así como los vacíos que tuvieron en muchos aspectos, los agremiados realizaron su trabajo sin mayores preocupaciones respecto a ellas o a la organización gremial, hasta finales del siglo XVII, cuando se comenzaron a vislumbrar signos de inquietud en muchos artesanos, entre ellos, arquitectos, pintores y entalladores; de hecho, desde aquella época, esas agrupaciones de artesanos cayeron en descrédito porque se llegó a considerar que se habían convertido en sociedades de complicidades que poco ayudaban al progreso de los oficios; esto, sin duda, coincidió con un cambio de mentalidad que produjo transformaciones tanto en la forma de organización de los artesanos, como en la producción artística misma.

Contrariamente a lo que ha sostenido en la historiografía tradicional, la Nueva España estuvo siempre al día en relación con las manifestaciones artísticas europeas. Más aún, los sistemas filosóficos y los avances científicos que impulsaron la creación artística fueron conocidos e incluso desarrollados en la Nueva España de manera paralela a Europa. Tal afirmación puede sustentarse precisamente a la luz del pensamiento ilustrado y la manera en que el arte se desarrolló a partir de la presencia de ese sistema filosófico que tuvo varias manifestaciones. Una de ellas fue la creación de teorías artísticas propias basadas fundamentalmente en la tradición local, aunque tomaran como punto de partida o guía la tratadística europea, de donde surgieron tratados artísticos escritos en la Nueva España y para la Nueva España.

Los tratados son instrumentos mediante los cuales se ordenan y se codifican los conocimientos de una determinada materia para su correcta aplicación. En México, se escribieron tratados desde el siglo XVII, como el compuesto por el carmelita, fray Andrés

\footnotetext{
${ }^{10}$ José Antonio Terán Bonilla, "La formación del gremio de albañiles de la ciudad de Puebla, en el siglo XVI y sus ordenanzas", Cuadernos Arquitectura Docencia 11 (1993): 14.

${ }^{11}$ Fernández, Arquitectura y gobierno virreinal. Los maestros mayores de la ciudad de México. Siglo XVII (CDMX: UNAM, IIE, 1985), 29, 287-291.
} 
de San Miguel ${ }^{12}$. No obstante, la toma de conciencia de los arquitectos respecto a la artisticidad de su quehacer, impulsó la elaboración de esos libros en el siglo XVIII. Así, por ejemplo, sabemos que entre las pertenencias del arquitecto novohispano José Eduardo de Herrera se encontraba "un cuaderno de a folio y dos de cuarto manuscriptos de este arte", es decir, del "arte de arquitectura" 13 , seguramente escrito por el propio Herrera, el cual, por desgracia, se encuentra perdido hasta ahora.

Entre los tratados novohispanos del siglo XVIII que se han localizado, se encuentra el titulado Architectura mechánica conforme a la práctica de esta ciudad de México ${ }^{14}$, atribuido hasta ahora al arquitecto Lorenzo Rodríguez y escrito a mediados de esa centuria. Más tardíos, pero igualmente importantes, son el tomo IV del tratado "en el que hay elementos de pintura, meteoros, statica, hidráulica, y algebra" escrito el año de 1778 por el sargento mayor Alexandro de la Santa Cruz Talabán ${ }^{15}$, así como la amplísima obra que el padre jesuita Pedro José Márquez escribió desde el exilio en Italia; entre los títulos más conocidos se encuentra Dell'Ordine Dórico ${ }^{16}$ y Sobre lo bello en general ${ }^{17}$.

Los pintores, hicieron lo propio, de manera que recientemente se encontró un tratado titulado El arte maestra. Discurso sobre la pintura. Muestra el modo de perficionarla con varias invenciones y Reglas practicas pertenecientes á esta materia, escrito a mediados del siglo XVIII y atribuido al pintor José de Ibarra ${ }^{18}$.

La preocupación central, manifiesta en todas esas obras, es la necesidad de que el trabajo que realizaban tanto arquitectos, como pintores, fuera reconocido como Arte Liberal. Así, el autor del mencionado tratado titulado Architectura mechánica conforme a la práctica de esta ciudad de México, afirmó que "La Escultura, la Pintura y Architectura, son las tres Bellas Artes, en virtud de las en París y en toda España, a su título se ordenan”. En tanto que, como bien afirma Myrna Soto, el título del tratado de pintura, El arte maestra, "nos revela una de las claves semánticas del texto, puesto que desde el encabezamiento el autor precisa afirmar la primacía de la pintura sobre el resto de las artes. Se entiende, así, como una implícita defensa al derecho de la pintura por ser reconocida

\footnotetext{
${ }^{12}$ Eduardo Báez Macías, Obras de fray Andrés de San Miguel, $2^{\mathrm{a}}$ ed. (CDMX: UNAM, IIE, 2007).

${ }^{13}$ María del Carmen Olvera Calvo, "La biblioteca de un arquitecto de la época virreinal en México", Boletín Monumentos Históricos 6 (1981): 40.

${ }^{14}$ El manuscrito se encuentra en el Fondo Reservado de la Biblioteca Nacional de México.

${ }^{15}$ Rocío Gamiño Ochoa, Alexandro de la Santa Cruz Talabán. Un tratado artístico y científico inédito, 1778 (CDMX: UNAM, IIE, 2012). Es de suponer que Alexandro de la Santa Cruz Talabán escribiera, al menos, los tres primeros tomos, pero desgraciadamente hasta hoy no han sido localizados.

${ }^{16}$ Pedro José Márquez, Dell'Ordine Dórico, ricerche didicate alla reale Academia di S. Luigi di Zaragoza da Pietro Márquez, messicano. Con apéndice sopra Una antica tavola di Pozzuolo (Roma: presso il Salomón, 1803), 138

17 Pedro José Márquez, Sobre lo bello en general. Discurso (s/1, Oficina del Diario, 1801). Pedro José Márquez: Sobre lo bello en general y dos monumentos de arquitectura mexicana: Tajín y Xochicalco, estudio y edición de Justino Fernández (CDMX: UNAM, IIE, 1972).

${ }_{18}$ Myrna Soto, El arte maestra. Un tratado de pintura novohispano (CDMX: UNAM, IIB, 2005).
} 
como arte liberal ..."19. De hecho, en otro documento, los pintores novohispanos afirmaron que "estas artes son liberales, científicas, ingenuas y nobles, y han merecido ser ocupación de reyes y príncipes" 20 .

En ese contexto teórico, se inserta la preocupación de los artistas por procurar su reorganización y la modernización de su quehacer, que había comenzado desde finales del siglo XVII, como lo manifiesta el hecho de que los pintores constituyeran una Academia, dirigida por los hermanos Juan y Nicolás Rodríguez Juárez, cuyo objetivo fue cambiar la manera de formar a los artistas y modernizar su propio trabajo. A esa Academia perteneció José de Ibarra, quien también fundó otra institución similar a mediados del siglo XVIII ${ }^{21}$.

Los arquitectos, por su parte, llevaron a cabo dos intentos para modificar las Ordenanzas de Albañilería que regían su gremio desde el siglo XVI. Una en $1735^{22}$ y otra en $1746^{23}$. En 1735, el maestro Pedro de Arrieta, junto con otros cinco arquitectos (Miguel José de Rivera, José Eduardo de Herrera, Miguel Custodio Durán, Manuel Álvarez y Francisco Valdez) presentó unas Ordenanzas formadas por los maestros veedores de arquitectura para su aprobación... ${ }^{24}$ con las que pretendieron regular la calidad de las construcciones y procurar que los arquitectos se responsabilizaran de sus actos en provecho de la sociedad; de ahí que, por ejemplo, regularan el precio de los "sitios" y "parajes" de la ciudad, para poder llevar a cabo avalúos justos y no dejar que "cada uno (según su alcance) ponga precios", por lo que el año de 1737 elaboraron un "mapa" de la ciudad de México que hoy se conoce precisamente como "Plano de Pedro de Arrieta", con ese objetivo".

Además de modernizar al gremio y de poner a la arquitectura al servicio de la sociedad, también fueron específicos en cuanto a los conocimientos científicos que debían tener los aspirantes a maestros, entre los que otorgaron especial importancia a la geometría, de manera que en la cláusula 11 de su propuesta, asientan que para llegar a ser maestro es preciso "el que hayan aprendido con escritura y con maestro arquitecto y examinado, con principios de geometría, por ser necesarísimo el que hayan de ejercitar todos los empleos como también el que sepa montear, reducir, quadrear, cubicar, etc.”.

El grupo de arquitectos reunidos alrededor de Pedro de Arrieta debieron de formar una especie de asociación que los hizo unidos y fuertes, al punto de establecer relaciones familiares entre unos y otros. Fue así que en 1746, ya muerto Arrieta, otro grupo de

\footnotetext{
${ }^{19}$ Soto, El arte maestra, 28.

${ }^{20}$ Mina Ramírez Montes, "En defensa de la pintura. Ciudad de México, 1753”, Anales del Instituto de Investigaciones Estéticas 78 (2001): 110, 117-118.

${ }^{21}$ Xavier Moyssén, "La primera Academia de Pintura en México", Anales del Instituto de Investigaciones Estéticas 34 (1965): 15-29.

${ }^{22}$ María Eugenia Reyes y Cabañas, "Las ordenanzas de arquitectura de la ciudad de México de 1735", Boletín de Monumentos Históricos 1 (2004): 41-49.

${ }^{23}$ Fernández, Arquitectura y gobierno virreinal, 31-43; 293-304.

${ }^{24}$ Reyes y Cabañas, "Las ordenanzas de arquitectura de la ciudad de México de 1735", 41-49.

${ }^{25}$ El plano se encuentra en el Museo Nacional de Historia del Castillo de Chapultepec.
} 
arquitectos que podríamos considerar como "sus herederos", conformado por Miguel Custodio Durán y Lorenzo Rodríguez -veedores del gremio-; Miguel Espinosa de los Monteros -maestro mayor de la Catedral y Real Palacio de México-; José Eduardo de Herrera -obrero mayor del Santo Oficio-; Manuel Álvarez -maestro mayor de la ciudad-; José de Roa, Bernardino de Orduña, José Antonio González e Ildefonso de Iniesta Bejarano y Durán, presentaron ante las autoridades civiles de la Nueva España, otro proyecto para reformar las Ordenanzas, en la que comienzan con la siguiente afirmación: "reconocidas las Reales Ordenanzas, en varias partes de ellas tiene la palabra Albañilería, y siendo Arte de Arquitectura, deberá intitularse así y tildarse Albañilería"26.

El grupo, fundado por Pedro de Arrieta, dominó el desarrollo de la arquitectura de la ciudad de México y, por extensión, de la Nueva España, hasta principios del siglo XIX y fue tan simbiótico, que muchas veces es imposible distinguir las obras de unos y otros, al grado de que se ha llegado a pensar que sus nombres eran menos importantes que mostrar su poder como congregación. Es así que podemos suponer que mientras los pintores se reunían en Academias, los arquitectos pudieron hacerlo en una especie de sociedad, a la manera de las masónicas, para encontrar una salida a la crisis gremial y a la necesaria modernización de su oficio.

Ésta, que es sólo una hipótesis, me parece que puede sustentarse con otros elementos como el manejo del concepto de Dios Arquitecto y la presencia de los Santos Coronados.

\section{El Gran Arquitecto del Universo y los Santos Coronados}

En relación con el concepto de El Gran Arquitecto del Universo, como afirma José Antonio Ferrer Benemeli, surgió en la Época Medieval y su representación iconográfica es la de Dios Padre, "como Creador, trazando el universo con un compás"27, idea que también estuvo presente en la cultura barroca novohispana, como lo deja ver el padre jesuita Juan de Goicoechea, en la obra que escribió con motivo de la inauguración del Santuario de Nuestra Señora de Guadalupe de la ciudad de México. Al referirse al "Soberano Artífice" que hizo los cielos y "fabricó para su adoración un Templo"; "el Templo de el Mundo":

porque lo fundó sobre los mares ... e ideó la machina sobre las corrientes de las aguas ... Él arqueó de la nada, sin la cimbra de la materia las bóvedas; Él sin profundar cimientos, estableció la Tierra ... Su Amor Artífice, trazó diligente essa maravilla sobre las ondas ... y de la transparencia de el Abysmo se congelaron las christalinas rocas de el Firmamento ... y quedaron unas bóvedas de los Cielos ...

\footnotetext{
${ }^{26}$ Fernández, Arquitectura y gobierno virreinal, 293.

${ }^{27}$ Ferrer Benimeli, La masonería española en el siglo XVIII, 14.
} 
Mucho tiene de parecido al Templo de el Mundo, este MARIANO Templo de GUADALUPE, fundado en el sitio inconstante de el Mexicano Lago, pero con la firmeza de aquel hermoso Cielo, que Trassumptó en el Ayate su dueño: y si copia el Templo a su Imagen, es este Templo una Imagen del Cielo ${ }^{28}$.

Del mismo modo, al describir el Santuario de Jesús Nazareno del pueblo de Atotonilco en el hoy Estado de Guanajuato, el año de 1768, el literato e impresor mexicano Manuel Antonio Valdez y Munguía explicó: “al mismo tiempo que se echaba el cordel para la medida de su fábrica, parece que el Cielo, como diestrísimo arquitecto, daba el modelo o mapa de su arquitectura”. Y más adelante agregó: “a vista de tanta maravilla desacierto hubiera sido grande haberle dado distinto plan de que el Cielo mostraba y así tomados los tamaños de todos se comenzó a cimentar la Octava Maravilla de su fábrica",29.

Igualmente, en la muy conocida leyenda fundacional de la ciudad de Puebla de los Ángeles, estructurada de manera definitiva por Diego Antonio Bermúdez de Castro en su Teatro Angelopolitano de $1746^{30}$, se afirma que la ciudad fue fundada por el obispo don Julián Garcés el 29 de septiembre de 1529, día de la festividad de San Miguel y su nombre se debía a que la víspera el prelado había tenido un sueño milagroso "en que le mostró Dios el sitio que le agradaba para la población de dicha ciudad" y en ese sitio, "vio su Ilustrísima unos "Ángeles echando unos cordeles y señalando la planta de la futura ciudad, midiendo sus cuadras y proporcionando sus calles"31. Al día siguiente, fray Julián Garcés salió a buscar el sitio y, al encontrarlo dijo: "Éste es el que mostró el Señor y donde quiere que se funde la Nueva Ciudad"32. En estos relatos, Dios muestra al obispo el paraje donde se había de fundar la ciudad por medio de ángeles quienes, además, son los encargados de trazarla

\footnotetext{
${ }^{28}$ Juan de Goycoechea, La maravilla inmarcesible, y milagro continuado de María Santíssima Señora Nuestra, en su prodigiosa imagen de Guadalupe de México. Compite firmezas con su nuevo Templo, que la copia: adelanta duraciones al Cielo, que a su Efigie traslada; iguala permanencias con el Augusto Sacramento, de quien imita la Milagrosa Presencia en su Pintura. Reproducido en Nueve Sermones Guadalupanos (1661-1758), selección y estudio introductorio de David A. Brading (CDMX: Centro de Estudios de Historia de México Condumex, 2005), 110-111.

${ }^{29}$ José de Santiago Silva, Apéndice documental. Atotonilco. Alfaro y Pocasangre (Guanajuato: Ediciones La Rana, 2004), 102.

${ }^{30}$ El nombre de la ciudad dio lugar a varias especulaciones, incluso en relación con su escudo de armas; varios autores se ocuparon de ello, especialmente a finales del siglo XVII y principios del siglo XVIII, pero fue Bermúdez de Castro, quien dio coherencia a los relatos y fijó la leyenda fundacional que conocemos hasta nuestros días. Al respecto véase: Fernández, Estudios sobre el simbolismo en la arquitectura novohispana (CDMX: UNAM, IIE, INAH, 2011), 393-412.

${ }^{31}$ Diego Antonio Bermúdez de Castro, Theatro Angelopolitano o Historia de la ciudad de la Puebla, ed. facsimilar (Puebla: Junta de Mejoramiento Moral, Cívico y Material del Municipio de Puebla, 1985). [1 ${ }^{\text {a }}$ ed.: 1746], 134.

${ }^{32}$ Bermúdez de Castro, Theatro Angelopolitano, 135. Mariano Fernández de Echeverría y Veytia: Historia de la fundación de la ciudad de la Puebla de los Ángeles en la Nueva España, su descripción y presente estado, 2 v., $2^{\mathrm{a}}$ ed., prólogo y notas de Efraín Castro Morales (Puebla: Ediciones Altiplano, 1962). [Escrita en 1780], I, 41-42.
} 
"por ilustración divina". ${ }^{33}$ Para los novohispanos, entonces, Dios fue arquitecto y urbanista y, aunque no se conocen hasta hoy, representaciones de Dios con el compás en la mano, es claro que la literatura de la época nos informa del acercamiento que tuvieron en la Nueva España a ese concepto.

Con respecto a los Santos Coronados, es preciso comenzar por decir que los gremios de la Nueva España estuvieron siempre vinculados a cofradías. El gremio de arquitectos y canteros de la ciudad de México tuvo una cofradía oficial, bajo el título de la de la Santa Cruz, establecida desde el año de 1657 en la capilla de Nuestra Señora de la Soledad de la Catedral de México; pero en el siglo XVIII y precisamente como consecuencia de la crisis gremial, un grupo selecto de arquitectos y canteros establecieron otra cofradía independiente que titularon de Nuestra Señora de los Gozos, la cual tuvo dos sedes: la primera, fundada en 1722 en la iglesia de Nuestra Señora de Belén y San Francisco Xavier ${ }^{34}$ y la segunda, establecida el año de 1723 en la iglesia del Espíritu Santo del Hospital de San Hipólito ${ }^{35}$. En cada una de esas iglesias, la cofradía levantó retablos, por desgracia hoy desaparecidos; sin embargo, la documentación que se refiere a ellos es muy sugerente.

En la del colateral que se levantaría en la iglesia de los padres bletemitas, se afirma que estaría dedicado a la Virgen de los Dolores (imagen que les donarían los mismos frailes) y "los santos de su arte" ${ }^{\text {" }}$. Por su parte, en el contrato celebrado con los padres del hospital de San Hipólito, se aclara que su advocación sería ya la de Nuestra Señora de los Gozos y en el retablo se colocaría la imagen titular "y demás santos sus patronos y de dicho su arte, 37 . Asimismo, una patente de la cofradía, firmada en 1750 por su mayordomo, el arquitecto José Eduardo de Herrera, se intitula: Patente de la Cofradía de Nuestra Señora de los Gozos, y Santos Architectos (imagen 1) ${ }^{38}$. Cabe entonces preguntarse ¿cuáles eran los santos "de su arte", o más específicamente, los "Santos Architectos"? ¿Acaso se referían a los Cuatro Santos Coronados, patronos de los masones?

\footnotetext{
${ }^{33}$ Mariano Fernández de Echeverría y Veytia, Historia de la fundación de la ciudad de la Puebla de los Ángeles, I, 40.

${ }^{34}$ María del Carmen Olvera Calvo y Ana Eugenia Reyes y Cabañas, "El gremio y la cofradía de los canteros de la Ciudad de México", Boletín de Monumentos Históricos 2 (2004): 47, nota 32.

${ }^{35}$ Olvera Calvo y Reyes y Cabañas, "El gremio y la cofradía de los canteros", 43-50.

${ }^{36}$ Énfasis añadido.

37 Énfasis añadido.

${ }^{38}$ Olvera Calvo y Reyes y Cabañas, "El gremio y la cofradía de los canteros", 48. Alicia Bazarte Martínez y Clara García Ayluardo, Los costos de la salvación, las cofradias y la ciudad de México (siglos XVI al XIX) (México: CIDE, IPN, AGN, 2001), 352.
} 
Imagen 1

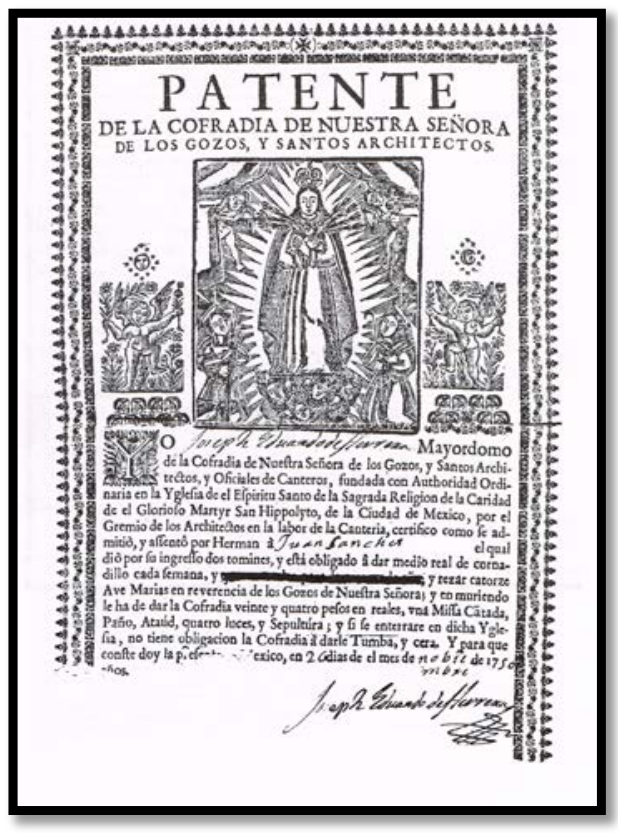

Patente de la Cofradía de Nuestra Señora de los Gozos y Santos Arquitectos, firmada el 26 de noviembre de 1750 por el arquitecto José Eduardo de Herrera. Imagen tomada de: Alicia Bazarte Martínez y Clara García Ayluardo, Los costos de la salvación, las cofradías y la ciudad de México (siglos XVI al XIX), México, CIDE, IPN y AGN, 2001, 352. Reprografía: Martha Fernández.

En el Museo de Arte de Davenport existe una pintura del siglo XVIII que se piensa del círculo de Miguel Cabrera -uno de los pintores más importantes de la Nueva España a mediados del siglo XVIII y miembro de la Academia fundada por José de Ibarra- en el que están representados Cinco Santos Coronados, esto es, los cinco escultores originales sacrificados el siglo III, por el emperador Dioclesiano; según el relato de Santiago de la Vorágine ellos eran Claudio, Castorio, Sinforiano, Nicóstrato y Simplicio ${ }^{39}$. Los instrumentos que portan en las manos en la pintura novohispana, así como las obras con las que se vinculan, indican que cuatro son escultores en madera y uno es cantero; de manera que como bien afirma Marcus B. Burke, no puede uno menos que relacionar a estos santos con las comunidades masónicas de arquitectos ${ }^{40}$. De cualquier manera, lo importante es que la pintura deja ver que en la Nueva España existió la advocación de los Santos Coronados, pero es preciso aclarar que ésta se presentó hasta el siglo XVIII y no fue una devoción popular, sino que, según dejan ver los testimonios expuestos, estuvo vinculada a gremios de artesanos, pero seguramente solo a ellos, lo que quiere decir que parece factible pensar que los santos patronos de los arquitectos que se colocaron en los retablos de la cofradía del Santo Ángel y Nuestra Señora de los Gozos pudieron ser, efectivamente, los Coronados (imagen 2).

\footnotetext{
${ }^{39}$ Santiago de la Vorágine, La leyenda dorada, 13a reimpresión (Madrid: Alianza Forma, 2008), II, 717. Al parecer, los cuatro que quedaron en el culto masón europeo fueron: Claudio, Nicóstrato, Simplicio y Sinforiano.

${ }^{40}$ Marcus B. Burke, “The Five Pannonian Masons as Woodcarvers”, Treasures of Mexican Colonial Painting (Davenport: The Davenport Museum of Art, 1998), II, 65-67.
} 
Acerca de ellos, José Antonio Ferrer Benemeli, explica que, junto con San Juan Bautista y San Juan Evangelista, fueron los patronos del gremio de albañiles durante el medievo y agrega que "figuran en lugar destacado en los correspondientes Estatutos de los Canteros de la época. Así, por ejemplo, los Estatutos de Ratisbona, de 1459, comienzan de esta forma: 'En el nombre del Padre, del Hijo, del Espíritu Santo, de la bienaventurada Virgen María, así como de sus bienaventurados siervos, los Cuatro Santos Coronados, a su memoria eterna" ${ }^{\prime 41}$. Es decir, que no es asunto menor para el estudio de la masonería en la Nueva España, la importancia que les pudieron conceder los gremios de artesanos a los Santos Coronados y, en este sentido, la información documental y la existencia de una pintura con esa representación, parece bastante elocuente.

Imagen 2

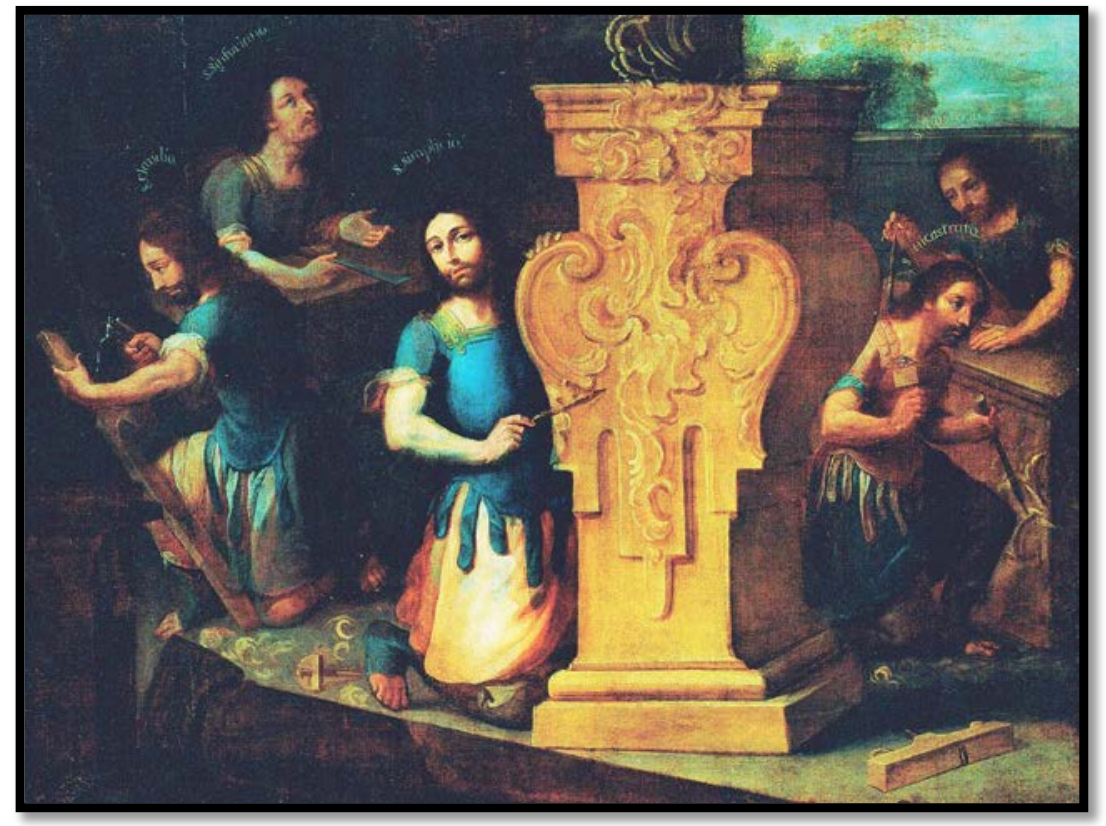

Los Cinco Santos Coronados, Museo de Arte de Davenport, EUA. Tomada de: Markus B. Burke: "The Five Pannonian Masons as Woodcarvers", Treasures of Mexican Colonial Painting, Davenport, The Davenport Museum of Art, 1998, 64. Reprografía: Martha Fernández.

\section{El Templo de Salomón: la Tienda cósmica}

Sin duda alguna, es claro que el modelo de cualquier templo cristiano es precisamente el diseñado por Dios y construido por el rey Salomón en Jerusalén, de ahí que no es de extrañar el interés salomonista que se tuvo en el México virreinal a lo largo de su

\footnotetext{
${ }^{41}$ Ferrer Benemeli, La masonería española durante el siglo XVIII, 19.
} 
historia incluida, por supuesto, la cultura del barroco. Del mismo modo, para la masonería, el Templo Masónico es la representación simbólica del Templo de Salomón ${ }^{42}$.

Pero el Templo de Salomón es, en realidad, la reunión conceptual de dos Templos diseñados por Dios y revelados a los judíos en diferentes momentos de su historia: la tienda que Moisés erigió al pie de Monte Sinaí y el Templo de piedra construido por Salomón. Ambos tuvieron una enorme trascendencia en la arquitectura cristiana desde la Época Medieval.

En un plano general, la concepción de los templos como tiendas, deriva de una cita bíblica del Antiguo Testamento. Para mostrar la omnipotencia de Yahvé, el profeta Isaías afirmó: "Él tiende los cielos como un toldo / y los despliega como una tienda de morada" (Isaías, 40:22). Aunque en el Nuevo Testamento, esta concepción está ausente, fue adoptada en la iconografía cristiana, seguramente por la influencia de la tradición judía, pero también de la romana, en la cual el Dios Coelus tenía la función de extender el manto curvo del cielo. De esta manera, "el manto a veces significa el firmamento, otras la cúpula que es su símbolo arquitectónico; otras la separación tierra-cielo, en relación con el velo del santuario, otras el mundo celeste"43. Es decir que, para la tradición judeocristiana, el cielo es concebido como la tienda cósmica que Dios extiende como cubierta de la tierra.

Aunque la idea del templo como tienda también puede tratarse de una representación del Templo de Salomón; de hecho, de la primera revelación de la casa de Dios en el cielo que Yahvé le transmitiera a Moisés al pie del Monte Sinaí cuando le ordenó que construyera un tabernáculo para custodiar el Arca de la Alianza. El templo que Dios le mandó levantar, antecedente del construido por Salomón, correspondía al de un pueblo en tránsito, que todavía estaba en busca de la "tierra prometida", por lo tanto, era propiamente una tienda desmontable y transportable, construida a base pieles y telas multicolores, tal como se describe en los textos escriturarios ${ }^{44}$.

La idea conceptual del templo como una tienda, también se presentó en la Nueva España; uno de los ejemplos más importantes es el que se refiere concretamente al Santuario de Nuestra Señora de Guadalupe. Cabe recordar que, en el proyecto para construirlo, el arquitecto José Durán, también pensó cubrirlo con bóvedas de nervaduras y así lo dejó ver en el dibujó que presentó hacia el año de 1695 (imagen 3). Aunque el Santuario, finalmente, no tuvo ese tipo de techumbre, el citado padre Juan de Goicoechea comparó la bóveda celeste con una capa; la capa con el Santuario de Guadalupe y, por

\footnotetext{
42 Juan Carlos Daza, Diccionario de la francmasonería (Madrid: Ediciones Akal, 1997), 364.

${ }^{43}$ Gérard de Champeaux y Dom Sébastien Sterckx, Introducción a los símbolos, trad. Abundio Rodríguez, O. S. B. (Madrid: Ediciones Encuentro, 1992), 83.

${ }^{44}$ Éxodo, 31:1-11. Todas las citas bíblicas están tomadas de la Sagrada Biblia, versión directa de las lenguas originales por Eloíno Nácar Fuster y Alberto Colunga, O. P. (Madrid: Biblioteca de Autores Cristianos, 1964).
} 
supuesto, también con la tilma de Juan Diego. De acuerdo con su visión, así como sucede con el vestido, "la capa del cielo se ha de envejecer"

y como quien muda de gala, y estrena vestido, has de estrenar, y mudar de Templo, y de Cielo, y el Cielo de tu Templo se ha de mudar en una Capa ... Pues Cielo Nuevo, que sea Capa, no hay otra, que la de Juan Diego, debajo de la Capa de el Cielo, porque con MARÍA, se trassundó todo el Cielo a aquella Capa ... Yo no dixera en el latino Idioma, con otra frase, lo que en el Mexicano Tylma, que cubre medio lado, como el Cielo, Capa de media Esphera ${ }^{45}$.

\section{Imagen 3}

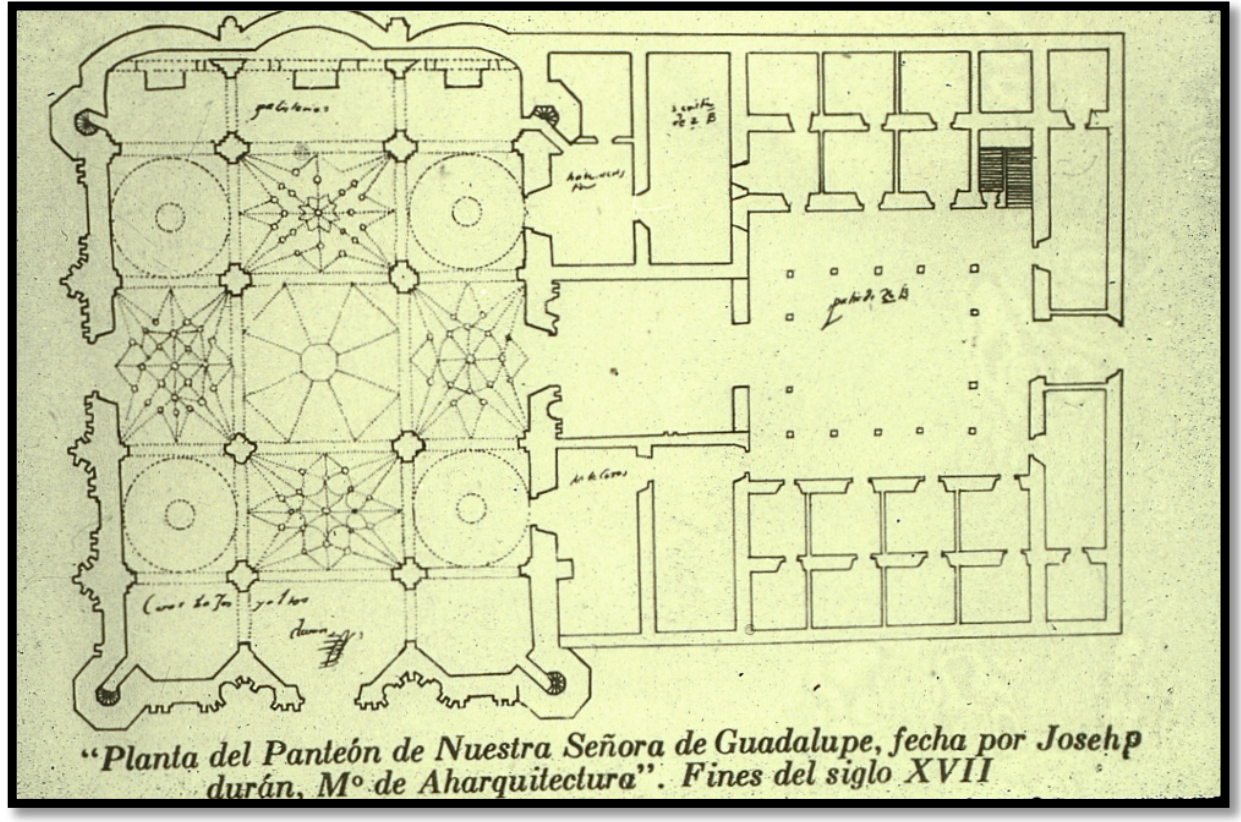

Planta del Santuario de Nuestra Señora de Guadalupe de la ciudad de México. Proyecto realizado por el arquitecto José Durán. Foto: Archivo Fotográfico "Manuel Toussaint”. IIE, UNAM.

Sin embargo, la idea de concebir el Templo como Tienda, no solamente la encontramos en la literatura. Para representar la Tienda cósmica y el Templo de Moisés, los arquitectos hicieron uso de varios recursos formales, aunque dos de ellos destacan por su belleza: el arco conopial y la bóveda de nervaduras. El arco conopial fue muy utilizado principalmente en el llamado gótico flamígero y tuvo gran difusión en el gótico isabelino español. Fue muy del gusto de la Nueva España desde el siglo XVI, sin que dejara de emplearse sino hasta la llegada del neoclásico. Existen muchos ejemplos de arcos conopiales en obras barrocas, entre ellos, el de la portada principal de la iglesia de la que fuera la Casa Profesa de la Compañía de Jesús en la ciudad de México (imagen 4),

\footnotetext{
${ }^{45}$ De Champeaux y Sterckx, Introducción a los simbolos, 113.
} 
construida por el arquitecto Pedro de Arrieta de 1714 a 1720, y los que se levantaron en el primer piso del antiguo claustro del convento de San Agustín, en la ciudad de Zacatecas, concluido en 1782 (imagen 5).

\section{Imagen 4}

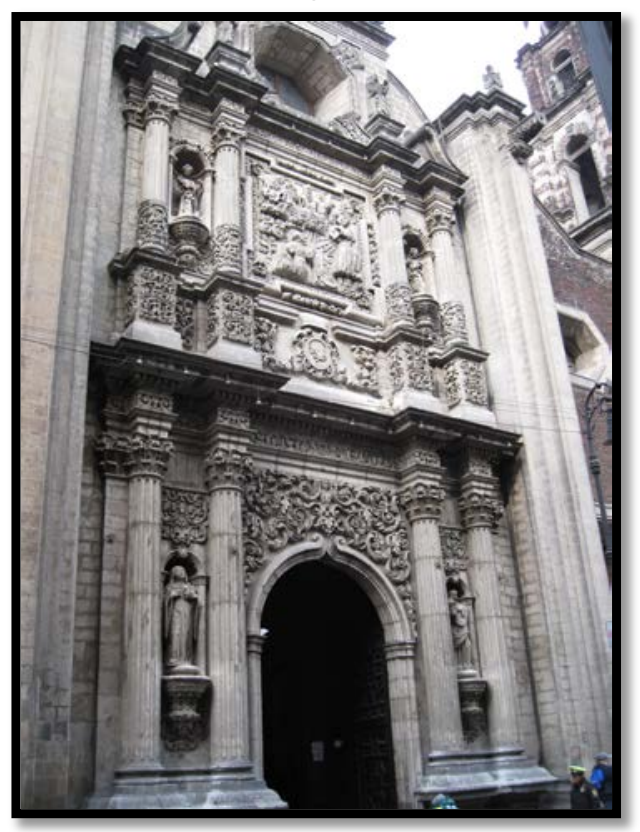

Portada principal de la iglesia de La Profesa, ciudad de México. Foto: Martha Fernández.
Claustro del que fuera el convento de San Agustín de la ciudad de Zacatecas, México. Los arcos conopiales se encuentran en la planta baja. Foto: Martha Fernández.

\section{Imagen 5}

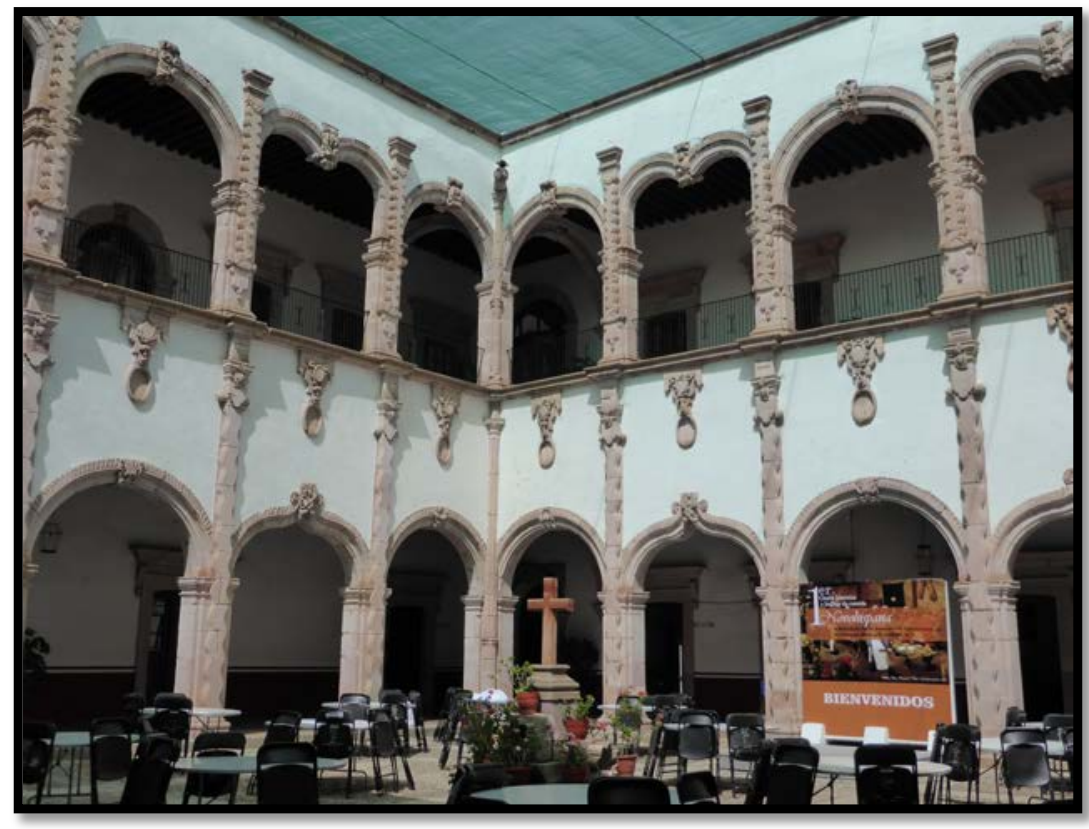


Por su forma, el arco conopial imita el vértice de cortinas o mantos abiertos, así lo deja ver, por ejemplo, el que remata la portada principal de la iglesia del Carmen de San Luis Potosí, edificada por el arquitecto indígena José Lorenzo, a mediados del siglo XVIII. Cortinas o mantos que dan paso a un templo, pero concebido éste como una tienda. (imágenes 6 y 7).

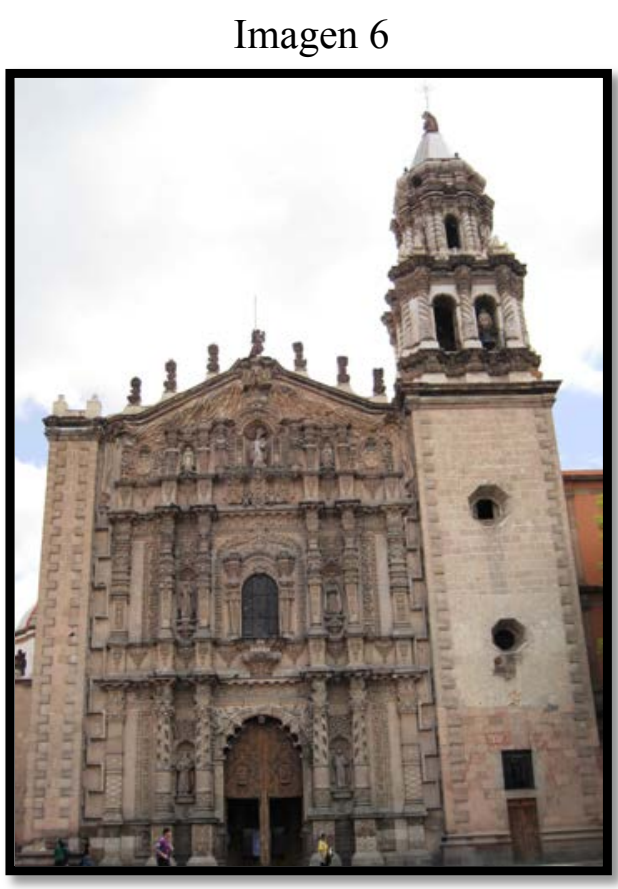

Fachada de la iglesia de Nuestra Señora del Carmen de la ciudad de San Luis Potosí, México. Foto: Martha Fernández.

\section{Imagen 7}

Remate de la portada de la iglesia de Nuestra Señora del Carmen de la ciudad de San Luis Potosí, México. Foto: Martha Fernández.

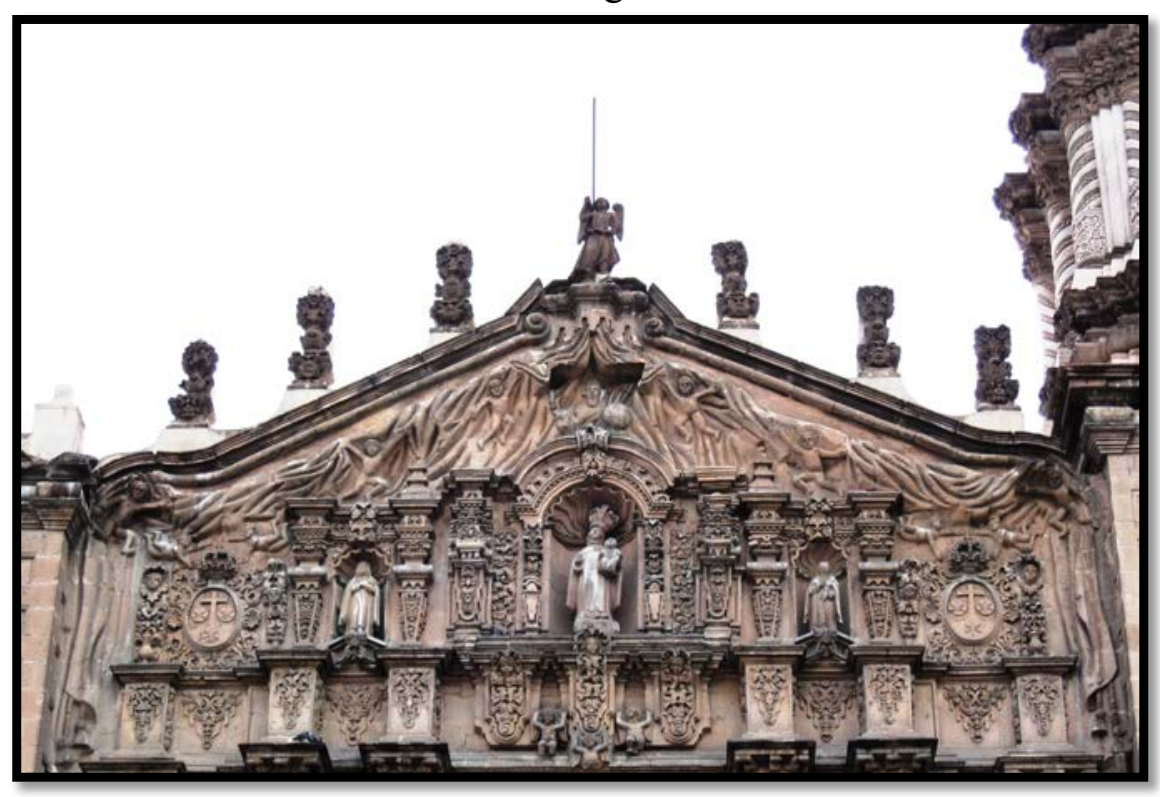


Por esa misma razón, varias iglesias barrocas de la Nueva España, construidas entre los siglos XVII y XVIII, fueron cubiertas con bóvedas de nervaduras, como la iglesia dedicada a la Virgen de Guadalupe de la ciudad de Querétaro, construida en 1680 (imagen 8) y la iglesia de Santa Mónica de Guadalajara, fundada el año de 1720 (imagen 9); así como algunos claustros, como el del convento de Santo Domingo de la ciudad de Oaxaca, asimismo del siglo XVIII (imagen 10). Las nervaduras, muy utilizadas en la arquitectura románica y gótica, simbolizan o bien las arrugas que se producen en las telas de una tienda cuando se tensan con las estacas, o bien las varillas con las que solían armar las tiendas en la antigüedad. Eran entonces, nuevamente la representación arquitectónica de la tienda cósmica o de la tienda de Moisés en el desierto.

Imagen 8

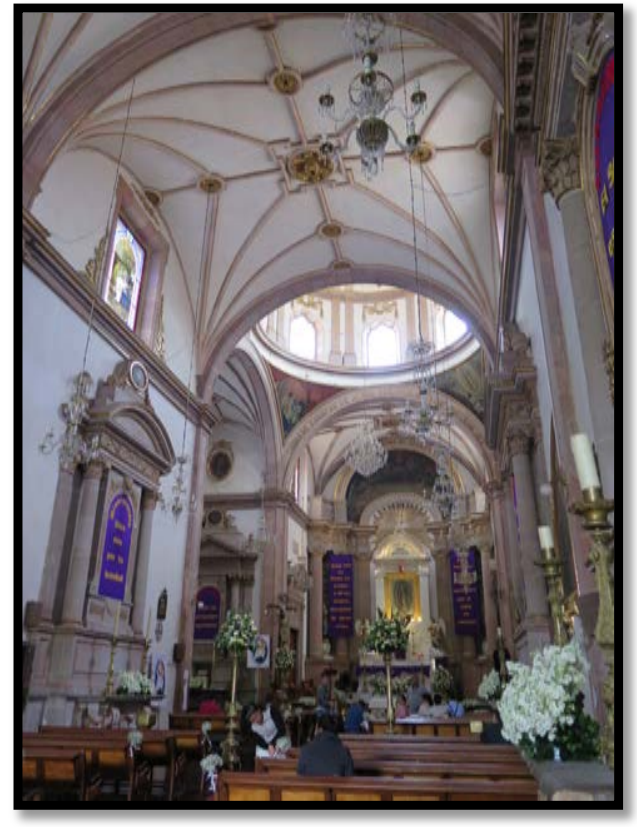

Bóvedas de nervaduras del interior de la iglesia de Nuestra Señora de Guadalupe, La Congregación, de la ciudad de Querétaro, México. Foto: Martha Fernández.
Imagen 9

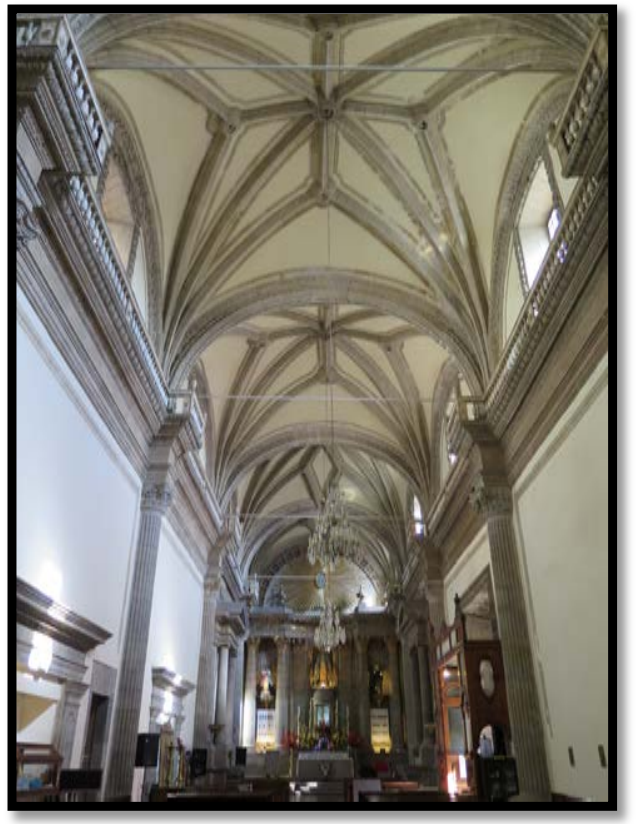

Bóvedas de nervaduras del interior de la iglesia de Santa Mónica de la ciudad de Guadalajara, Jalisco, México. Foto: Martha Fernández.

Es importante insistir en que, como mencioné antes, las expresiones artísticas del barroco, son consideradas como las más representativas de la cultura novohispana; las que la dotaron de identidad propia. En cuanto a la arquitectura, no se puede negar el esplendor que alcanzaron sus edificios y sus retablos; tampoco su originalidad y, ciertamente, su particular desarrollo artístico; por ello, no deja de llamar a atención el hecho de que en esas obras encontremos elementos rescatados del arte medieval europeo como los arcos 
conopiales y las bóvedas de nervaduras. Como he dicho, ambos elementos están vinculados con la concepción de la Tienda cósmica y del Templo de Moisés, no obstante, no debemos soslayar el hecho de que en las logias masónicas, el trono del maestro, que recuerda el Trono de Salomón, es también representado como una tienda en diversos grabados y pinturas del Arco Real, (imagen 11) como algunos que se encuentran en la Library and Museum of Freemasonry de Londres; de manera que cabe una pregunta: ¿acaso los arcos conopiales y las bóvedas de nervaduras en la Nueva España, también pudieron pretender representar la Tienda del maestro masón?

Imagen 10

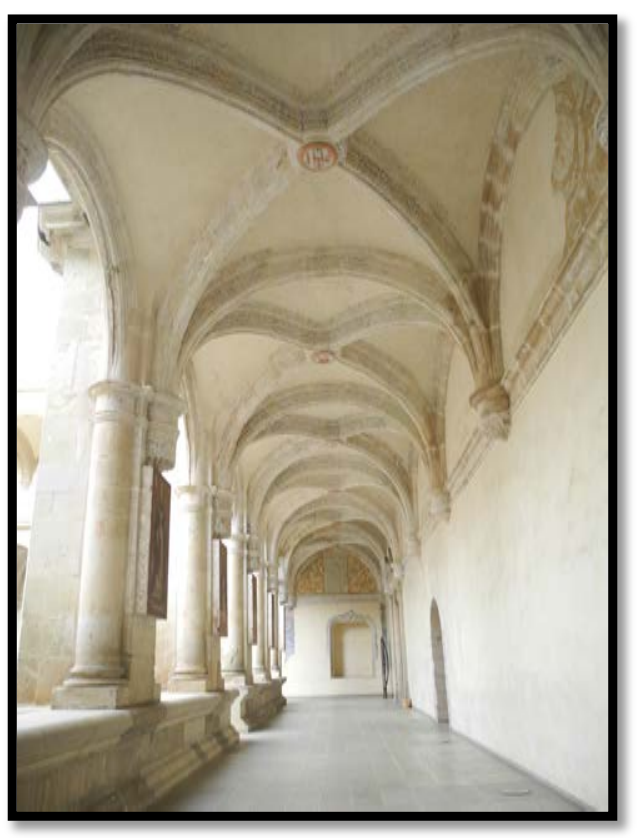

Bóvedas de nervaduras del claustro bajo del que fuera el convento de Santo Domingo de la ciudad de Oaxaca, México.
Imagen 11

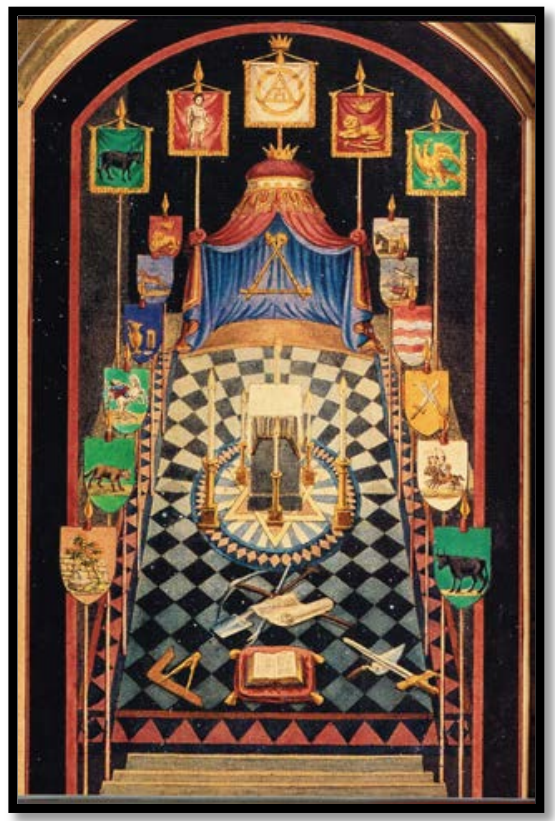

Cuadro del Arco Real Sagrado, Library and Museum of Freemasonry de Londres. Tomado de W. Kirk MacNulty: Masonería. Símbolos, secretos, significado, Barcelona, Editorial Electa, 2006, 186. Reprografía: Martha Fernández.

\section{EI Templo de Salomón: Jachín y Bóaz}

Entre los elementos más importantes que tuvo el Templo construido por Salomón en Jerusalén, se encuentran las columnas que flanqueaban su pórtico. De acuerdo con los textos escriturarios, el rey judío "asentó las dos columnas ... y alzado que hubo la de la derecha, llamóla Jachín; levantada igualmente la segunda, le puso por nombre Boaz”,46.

\footnotetext{
${ }^{46}$ I Reyes, 8:15-22; Crónicas: 4:12-17.
} 
Para la masonería, las dos columnas del Templo han tenido y tienen una importancia capital. Marcan los límites del mundo profano y representan la dualidad: Jachín es el pilar de la misericordia; es masculina y activa, y corresponde al Sol. Boáz, se relaciona con el pilar de la severidad; es femenina y pasiva, y se relaciona con la Luna ${ }^{47}$.

Según los relatos bíblicos, esas columnas eran: "cada una de diez y ocho codos de alto; daba vuelta a cada columna un cordón o moldura, de doce codos"48. La interpretación que se dio a esas características arquitectónicas, llevó a que se pensara que las columnas del Templo eran helicoidales; de hecho, el rey Constantino las utilizó en el tabernáculo que construyó en la primitiva basílica de San Pedro de Roma, como se aprecia en la pintura titulada La Donación de Roma al Papa Silvestre I, que pintaron Giulio Romano y Giovanni Francesco Penni en la Sala de Constantino en el Vaticano, el año de 1520 (imagen 12). Igualmente, otra tradición indica que en una de esas columnas -cuando se encontraban en el Templo de Salomón- se apoyaba Cristo cuando predicaba en ese recinto, por lo que ahora se le conoce como Columna Santa y se encuentra custodiada en el Museo de la basílica vaticana (imagen 13).

\section{Imagen 12}

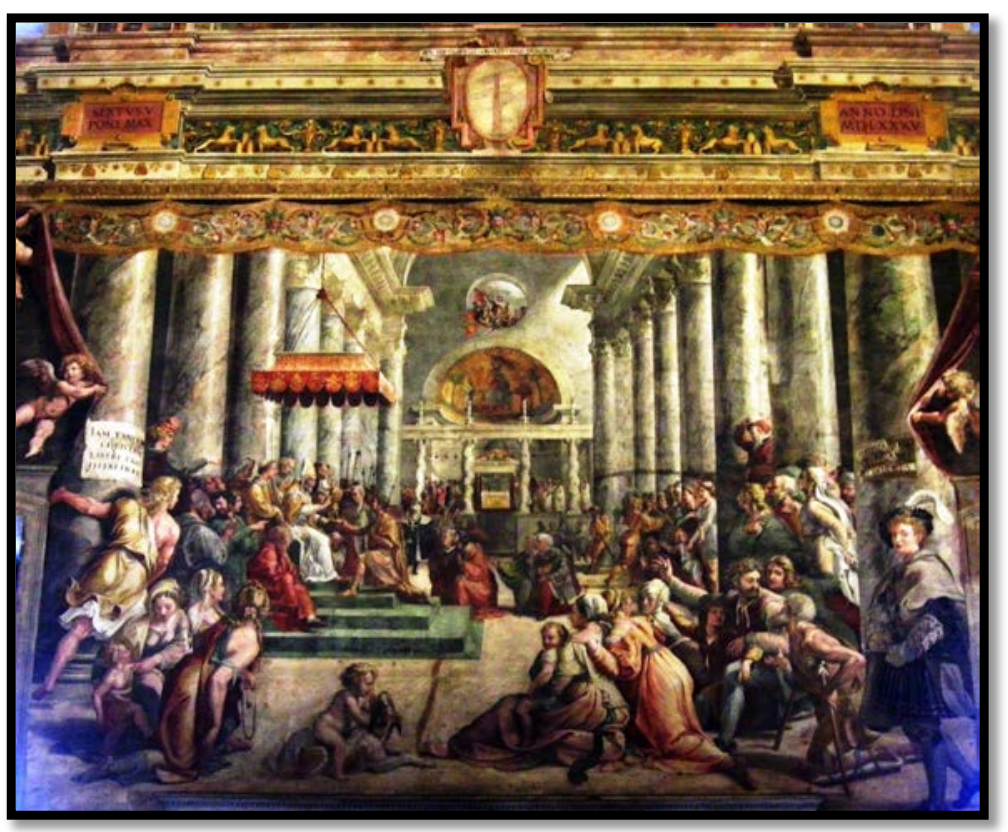

Giulio Romano y Giovanni Francesco Penni: La Donación de Roma al Papa Silvestre I, Sala de Constantino, Museos del Vaticano, 1520. Foto: Martha Fernández.

\footnotetext{
${ }^{47}$ Daza, Diccionario de la francmasonería, 88.

${ }^{48}$ I Reyes, 7:15-22.
} 
Imagen 13

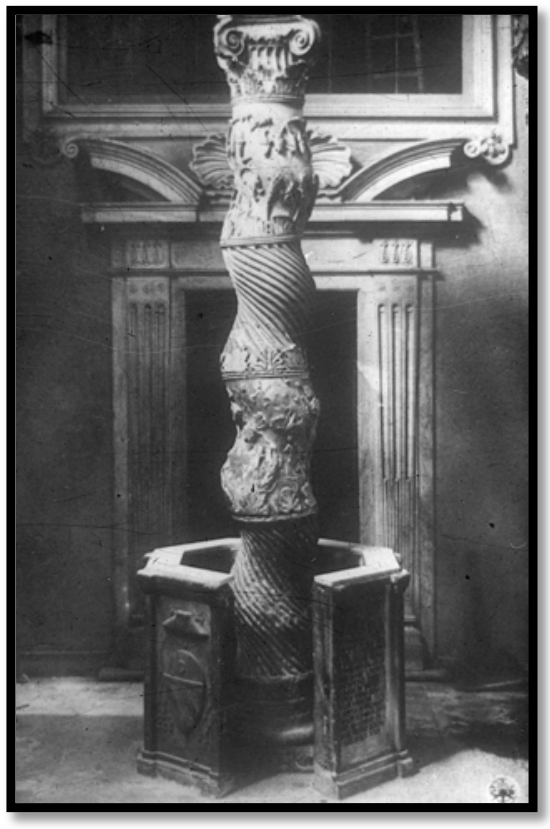

Columna Santa, basílica de San Pedro del Vaticano. Foto: Archivo Fotográfico "Manuel Toussaint”. IIE, UNAM.

En la arquitectura cristiana, se realizaron columnas helicoidales, en referencia al Templo de Salomón, desde la Época Medieval, como se puede apreciar en los claustros romanos de San Juan de Letrán y San Pablo Extramuros (imagen 14). Después de algunas polémicas que se presentaron durante el siglo XVI, la obra que dio carta de naturaleza a esas columnas en la arquitectura cristiana, fue el afamado Baldaquino de San Pedro, que construyó Gianlorenzo Bernini de 1624 a 1633, en la Basílica del Vaticano (imagen 15) ${ }^{49}$.

\footnotetext{
${ }^{49}$ Fernández, La imagen del Templo de Jerusalén en la Nueva España (CDMX: UNAM, CH, 2003), 51-56.
} 
Imagen 14

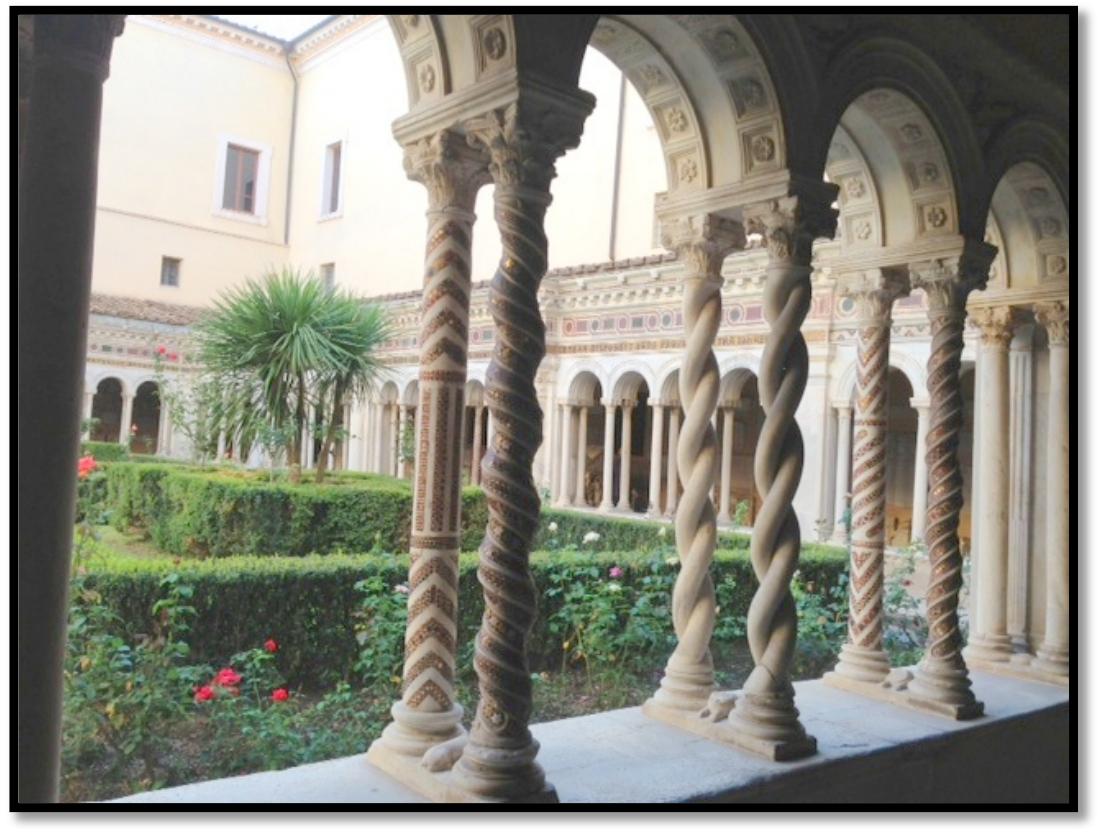

Claustro del convento de San Pablo Extramuros, Roma, Italia. Foto: cortesía de Olga Sáenz González.

Baldaquino de San Pedro, basílica de San Pedro del Vaticano. Foto: Martha Fernández.

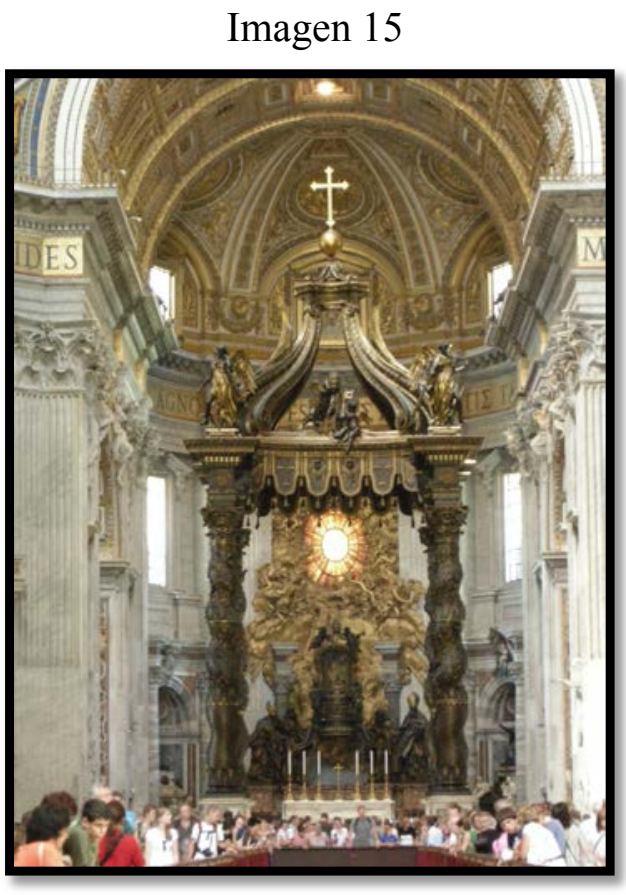

Sin embargo, las helicoidales no fueron los únicos soportes que se utilizaron para recordar a Jachín y Bóaz. El tratadista Sebastián Serlio, por ejemplo, en la lámina XIII de las "puertas de orden elegante" de su Libro Sexto o Extraordinario de su tratado, propuso una columna recta dividida en tercios: el primer tercio tiene estrías verticales; el segundo, 
estrías diagonales y, el tercero, una trama de bandas entrecruzadas (imagen 16) ${ }^{50}$. Las estrías diagonales, recuerdan las estrías de la Columna Santa y, por lo tanto, puede considerarse salomónica y, la trama del último tercio, puede quizá representar, la "red de cadenas entrelazadas" que cubrían "los capiteles asentados sobre pezones de granadas" de las columnas del Templo construido por Salomón ${ }^{51}$.

Imagen 16

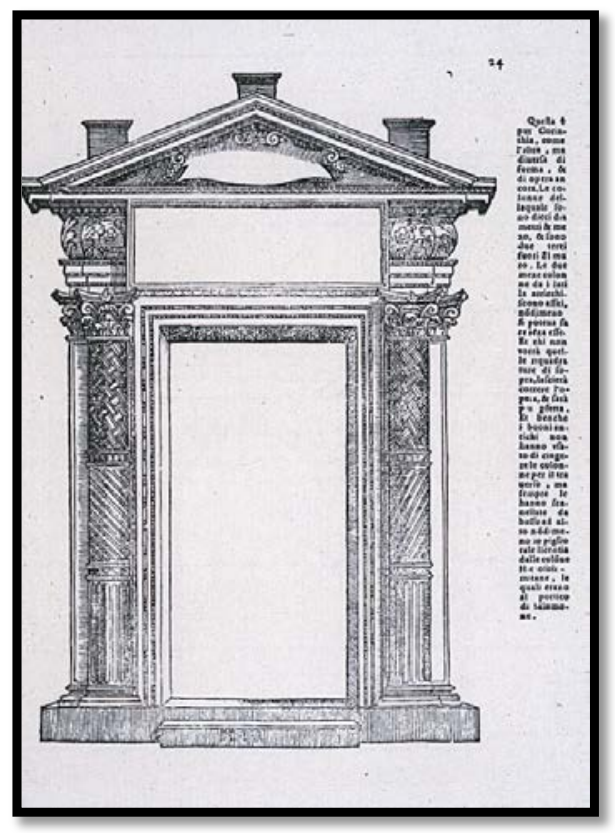

Sebastián Serlio: Tratado de Arquitectura, Libro VI o Libro Extraordinario, lám. XIII. Reprografía: Martha Fernández.

Por su parte, otro tratadista, Guarino Guarini, en su Architectura civile, propuso columnas salomónicas a base de estrías ondeantes y en zigzag. Precisa que ese tipo de estrías se podían hacer en sentido horizontal ("a someglianza di onde") o en sentido vertical ("dall'alto al basso") ${ }^{52}$. Este tratadista, incluso, llegó a concebir la pilastra de perfil ondeante, como una variante del soporte salomónico y con ellas construyó la fachada de la iglesia de La Divina Providencia, en Lisboa, el año de 1653 (imagen 17) ${ }^{53}$. Es decir, que las columnas de estrías móviles también pueden ser consideradas como salomónicas en tanto hacen referencia o recuerdan las columnas del Templo hierosolimitano.

\footnotetext{
50 Sebastián Serlio, Todas las obras de arquitectura y perspectiva de Sebastián Serlio de Bolonia, introducción "La fortuna de Sebastián Serlio" por Carlos Sambricio, estudio lingüístico y edición castellana al cuidado de Fausto Díaz Padilla, 2 t. (Oviedo: Colegio Oficial de Aparejadores y Arquitectos de Asturias, 1986), II, 59-60.

${ }^{51}$ I Reyes, 7:15-22.

${ }^{52}$ Guarino Guarini: Architettura civile, introducción de Nino Carboneri, notas y apéndices de Bianca Tavessi La Greca (Milán, Italia, Edizioni il Polifilo, 1968) [1ª ed., 1737], 171, 193.

${ }^{53}$ La iglesia se destruyó con el terremoto de 1755.
} 
Imagen 17

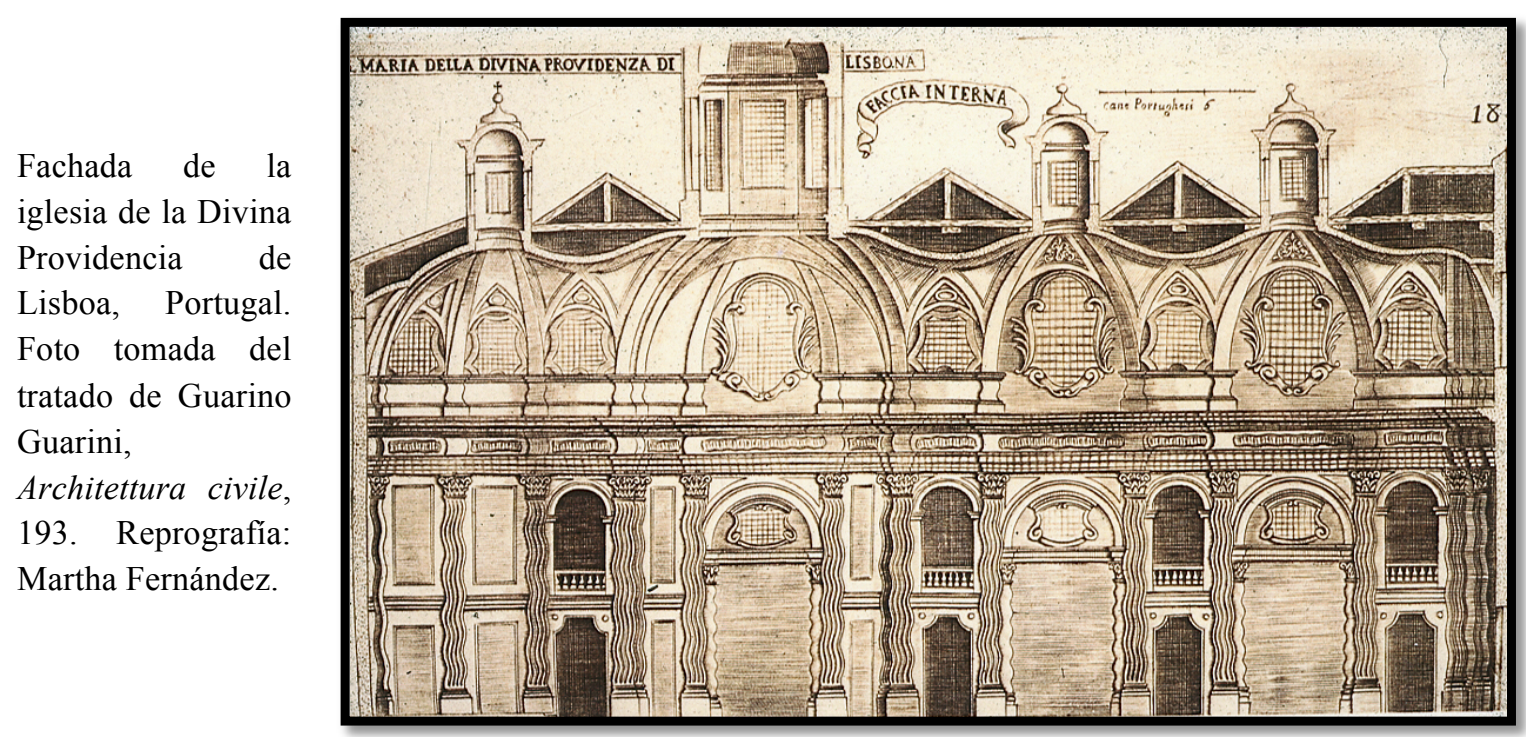

Desde luego, en la Nueva España se levantaron muchas columnas salomónicas desde el siglo XVI, asimismo con la intención de reproducir las del pórtico del templo salomónico, aunque la que hasta hoy se considera la primera obra barroca con columnas helicoidales, es el Retablo de los Reyes de la Catedral de Puebla, proyectado y construido por el ensamblador Lucas Méndez entre 1646 y 1649 (imagen 18); a partir de entonces encontramos una gran cantidad de soportes helicoidales con una muy extensa variedad de tipos de torsión y una enorme riqueza de elementos simbólico-ornamentales, aunque los más parecidos a la Columna Santa son los que flanquean la portada de la capilla de Nuestra Señora de Loreto en la ciudad de San Miguel Allende, en el Estado de Guanajuato, construida el año de 1738 (imagen 19). 
Imagen 18

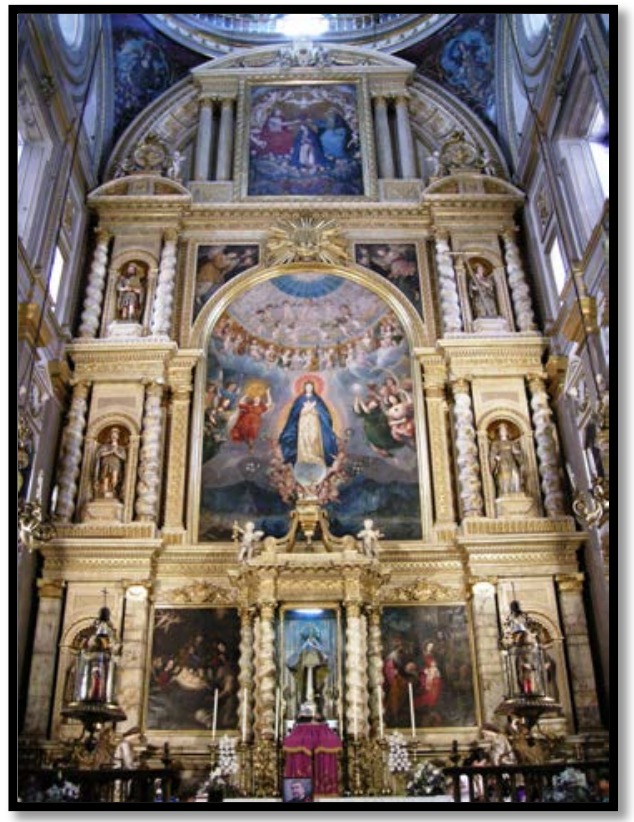

Retablo de los Reyes de la Catedral de Puebla, ciudad de Puebla, México. Foto: Martha Fernández.

Portada de la iglesia de Nuestra Señora de Loreto de la ciudad de San Miguel de Allende, Guanajuato, México. Foto: Martha Fernández.

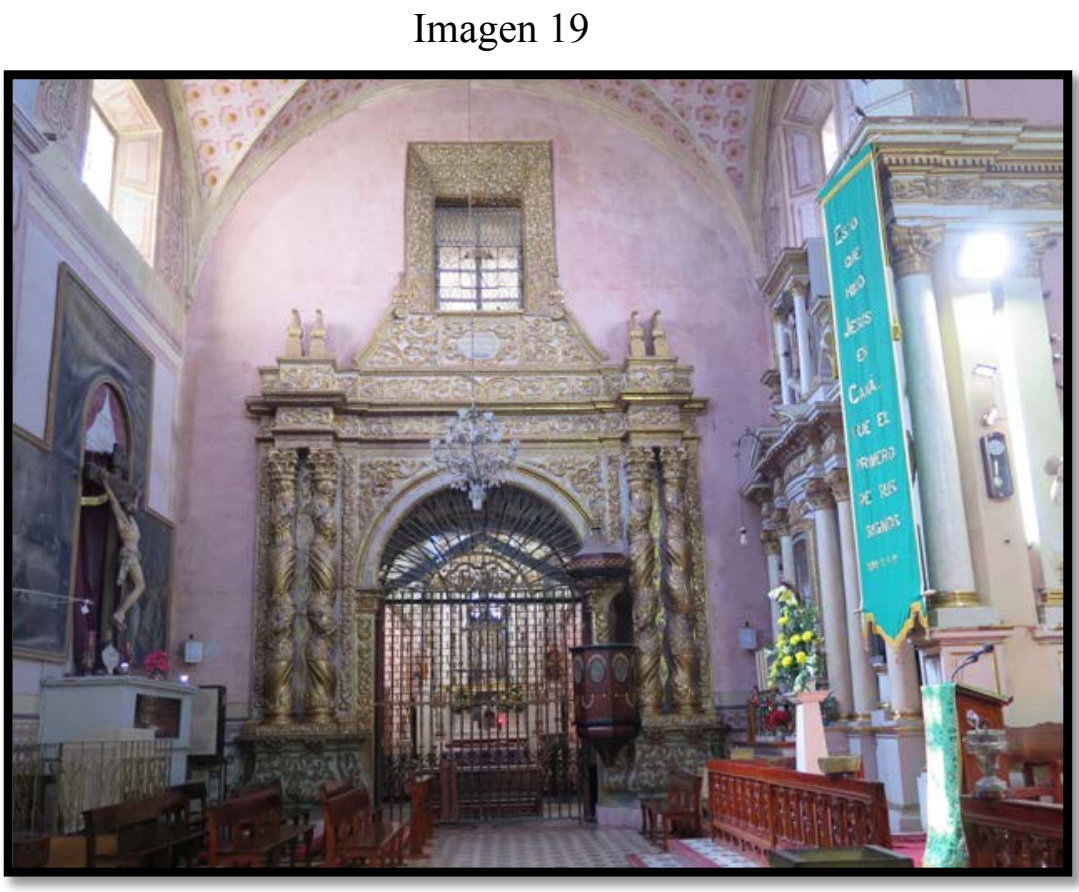

Resultan obvias en su sentido simbólico, las que flanquean el relieve del segundo cuerpo de la iglesia de San Agustín de la ciudad de México, que representa el patrocinio del santo, pues tiene inscripciones en latín alusivas a Agustín como Nuevo Salomón y a la construcción del templo espiritual y temporal. Así, al pie de las figuras se lee: “Tú Salomón 
de la Nueva Ley, Fuente de vida Sabiduría. La utilidad que tú solo prestas a la Fe es mayor que el daño que le causan todas las herejías". Y debajo del relieve, otra inscripción, tomada del Capítulo I, versículos 1 y 2 del libro del Eclesiastés, dice: "He aquí el Gran Sacerdote, que en su vida fortificó el Templo. Por él fue también fundada la altura del Templo, la doble fábrica" ${ }^{54}$ (imagen 20).

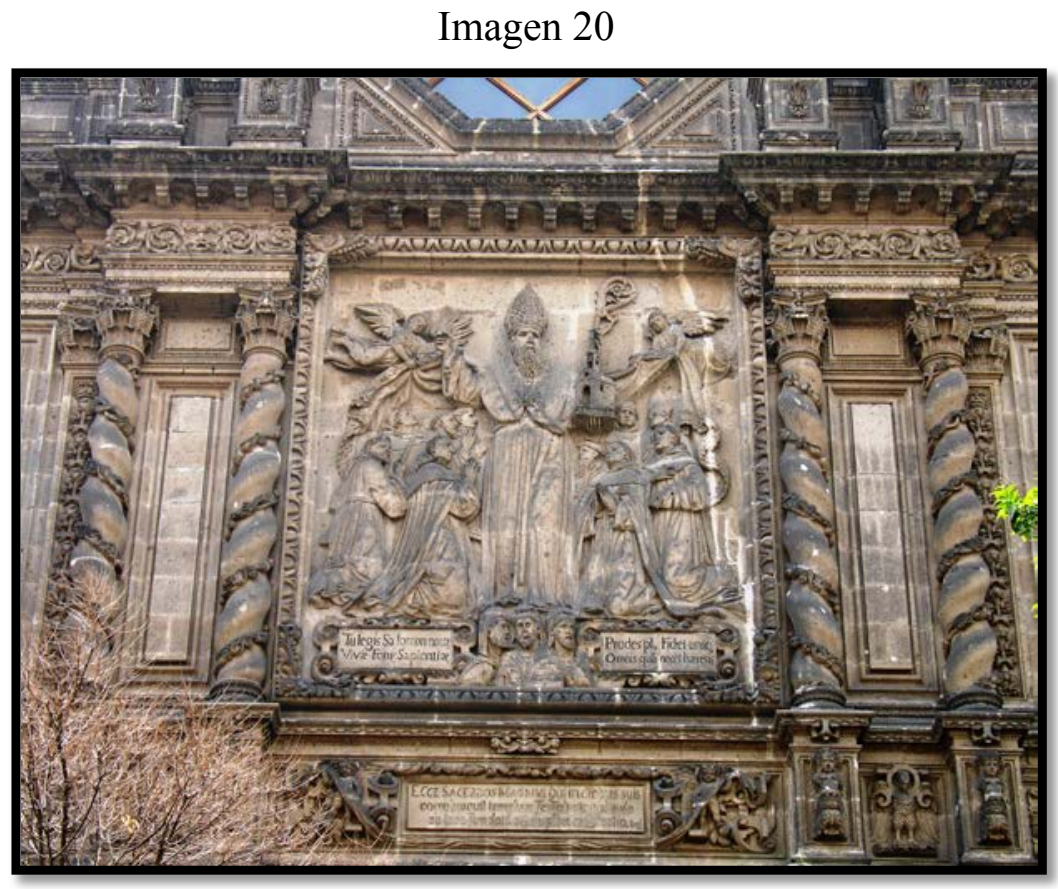

Anónimo: El patrocinio de San Agustín, relieve del segundo cuerpo de la portada de la ex iglesia de San Agustín de la ciudad de México (hoy patrimonio de la UNAM). Foto: Martha Fernández.

También se levantaron columnas salomónicas con otras características formales; entre ellas, las propuestas por Guarini. Este tipo de soportes se utilizaron con mucha frecuencia en la Nueva España, con todas sus variantes, pero es interesante rescatar, sobre todo las columnas y pilastras con estrías muy triangulares, a manera de espigas, como las que el arquitecto Diego de la Sierra empleó en dos de sus obras más importantes: la Casa de las Bóvedas (1684-1685) (imagen 21) y la capilla de Jesús Nazareno de la parroquia de San José (principios del siglo XVIII), ambas en la ciudad de Puebla (imagen 22). Lo interesante es que sus fuentes no parecen encontrarse en obras o tratados contemporáneos, sino en obras medievales, como las catedrales de Durham en Inglaterra (1093-1133) y de Reims en Francia (1230-1260), así como los claustros conventuales de San Pablo Extramuros y San Juan de Letrán, de Roma (1200) (imagen 23). En el siglo XVIII, el uso de estrías en zigzag

\footnotetext{
${ }^{54}$ Después de un incendio que sufrió la iglesia el 11 de diciembre de 1676, tuvo que ser reconstruida. La portada principal fue diseñada y levantada por el arquitecto Cristóbal de Medina Vargas el año de 1681. Martha Fernández, Cristóbal de Medina Vargas y la arquitectura salomónica en la Nueva España durante el siglo XVII (CDMX: UNAM, IIE, 2002), 235-236.
} 
muy marcadas y pronunciadas (triangulares, se podría decir), a manera de espigas, se extendió hasta Oaxaca, como se aprecia en la portada de la iglesia de la Merced y no faltan ejemplos en la ciudad de México, como lo manifiesta la que fuera la iglesia de San Diego, en Tacubaya.

\section{Imagen 21}

Columnas espigadas y con estrías móviles del segundo piso del patio de la Casa de las Bóvedas de la ciudad de Puebla, México. Foto: Martha Fernández.

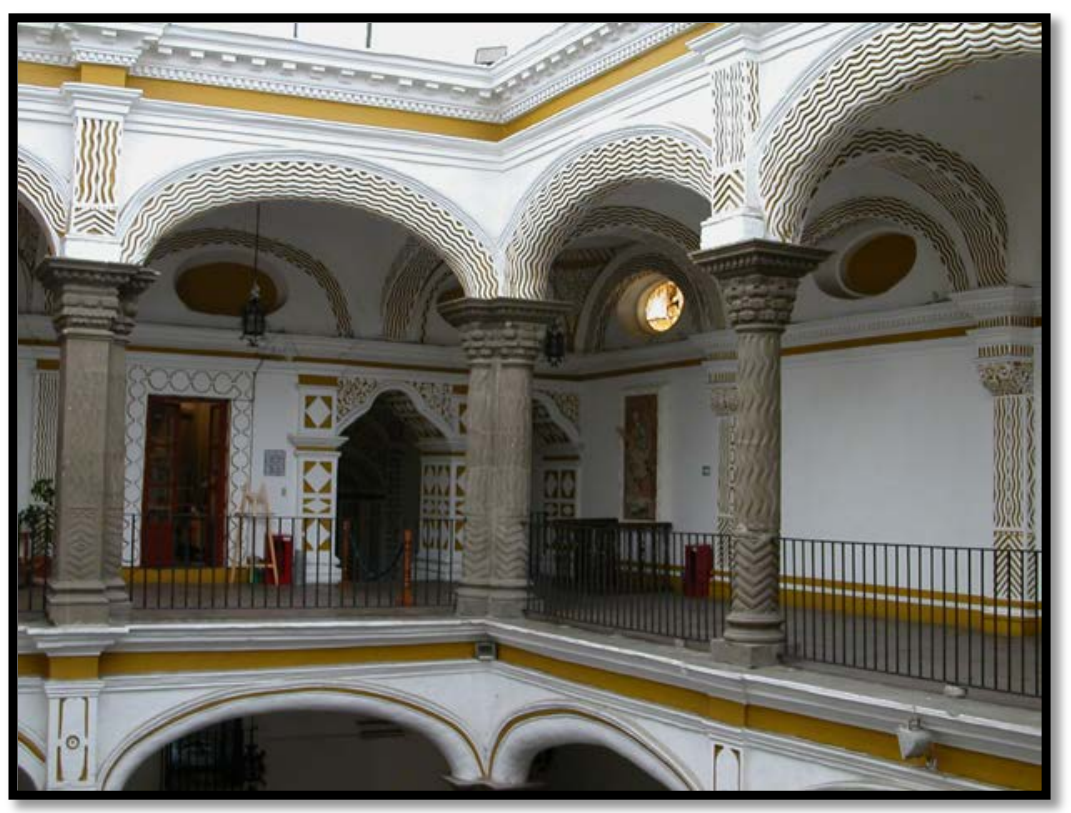

\section{Imagen 22}

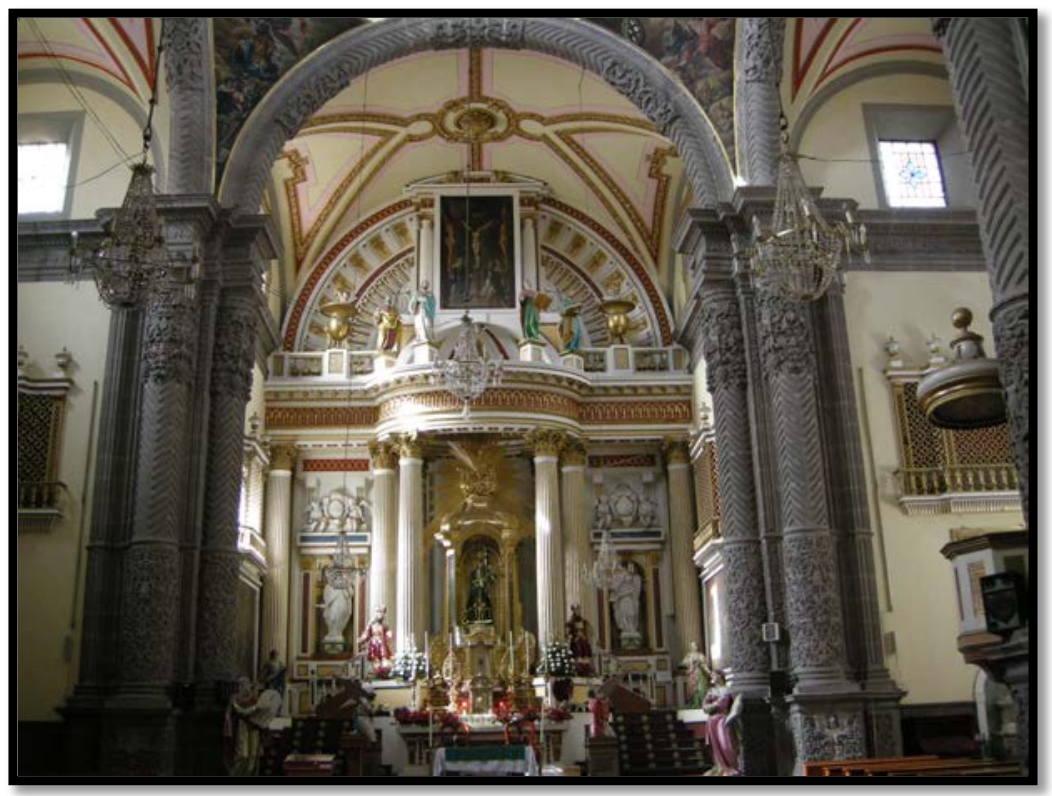

Columnas espigadas del interior de la capilla de Jesús Nazareno de la Parroquia de San José de la ciudad de Puebla, México. Foto: Martha Fernández. 


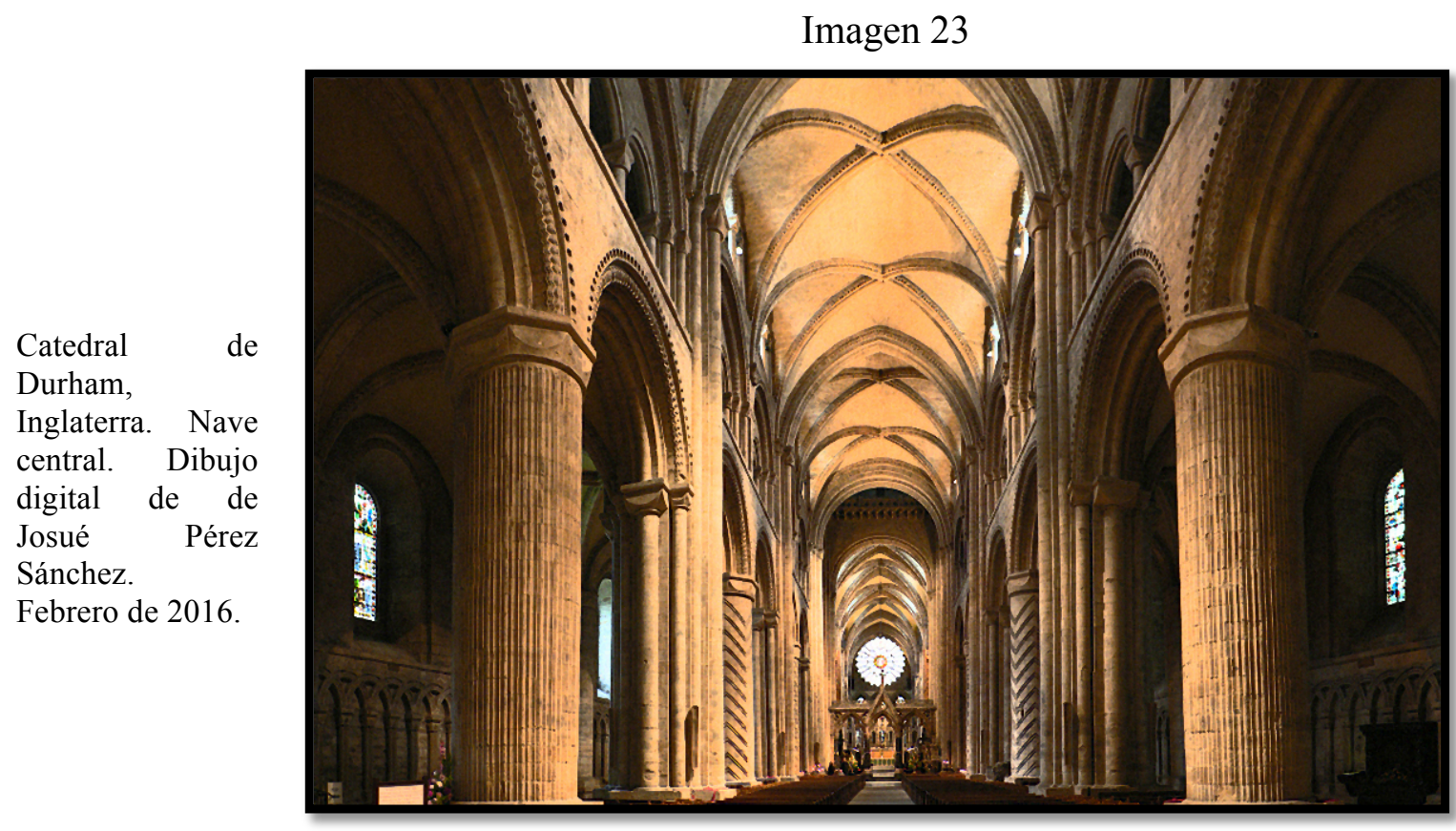

Pero las estrías en zigzag no solamente fueron utilizadas en los fustes de manera horizontal, sino también en sentido vertical (d'alto al basso, diría Guarini), como podemos apreciarlo en las columnas de varios edificios zacatecanos, como en la que fue la portada de la iglesia de San Francisco (imágenes 24 y 25), construida por el arquitecto Juan Lazcano de 1686 a 1689 y las que soportan y adornan el interior de la Catedral de Zacatecas, construida de 1729 a $1785^{55}$ (imagen 26). En estas obras volvemos a encontrar un notable parecido con obras románicas españolas, como la ermita de Nuestra Señora de las Vegas, en Requijada, Segovia y la abadía cisterciense de San Andrés del Arroyo, en Palencia, ambas edificadas entre los siglos XII y XIII (imagen 27). A estas columnas se les ha atribuido un simbolismo solar como expresión de la difusión de la luz de Cristo que viene de oriente y se propaga a occidente.

\footnotetext{
${ }^{55}$ Proyectada por Domingo Ximénez Hernández entre 1720 y 1731. Su construcción se llevó a cabo de 1729 a 1785.
} 
Imagen 24

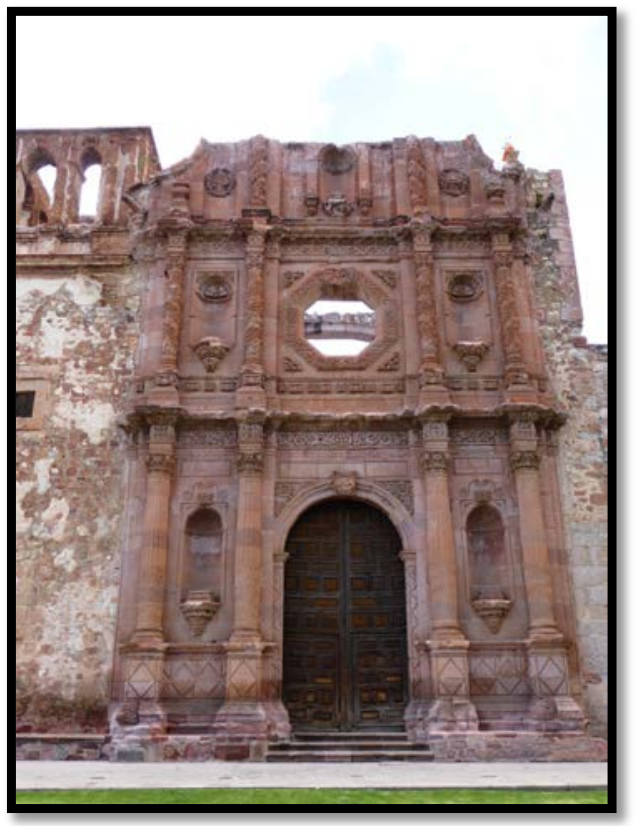

Portada de la que fuera la iglesia de San Francisco de la ciudad de Zacatecas, México. Foto: Martha Fernández.

Imagen 26

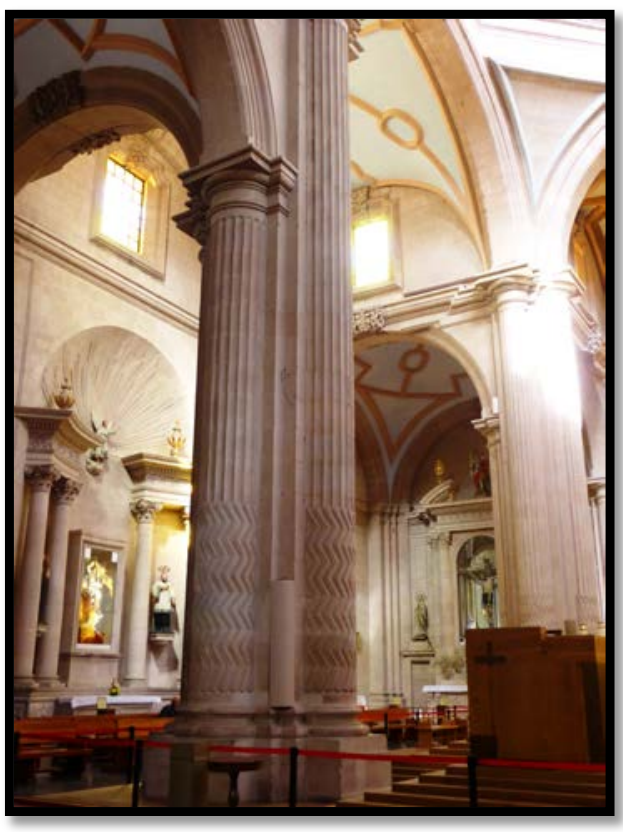

Columnas del interior de la Catedral de Zacatecas, México, con estrías en zigzag. Foto: Martha Fernández.
Imagen 25

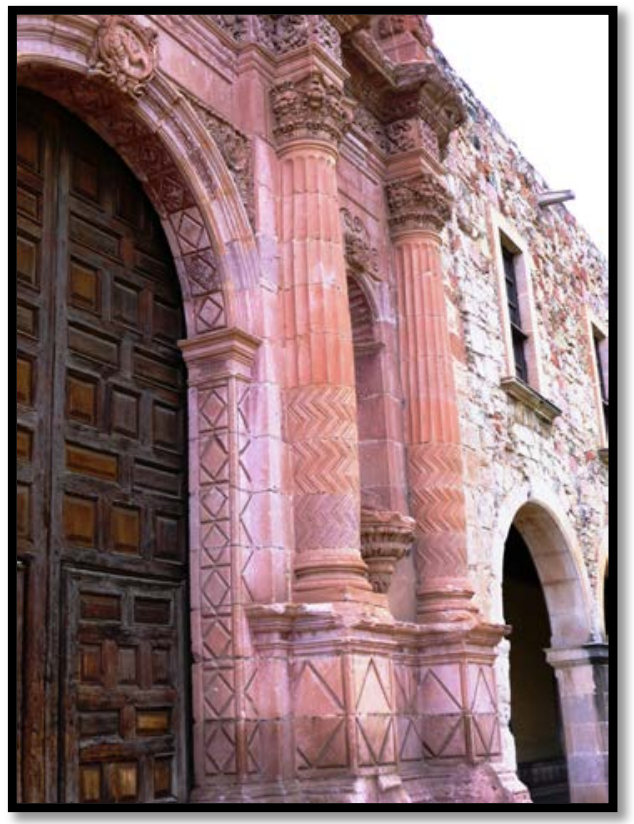

Columnas de la portada principal de la iglesia de San Francisco de la ciudad de Zacatecas, México, con estrías en zigzag. Foto: Martha Fernández.

\section{Imagen 27}

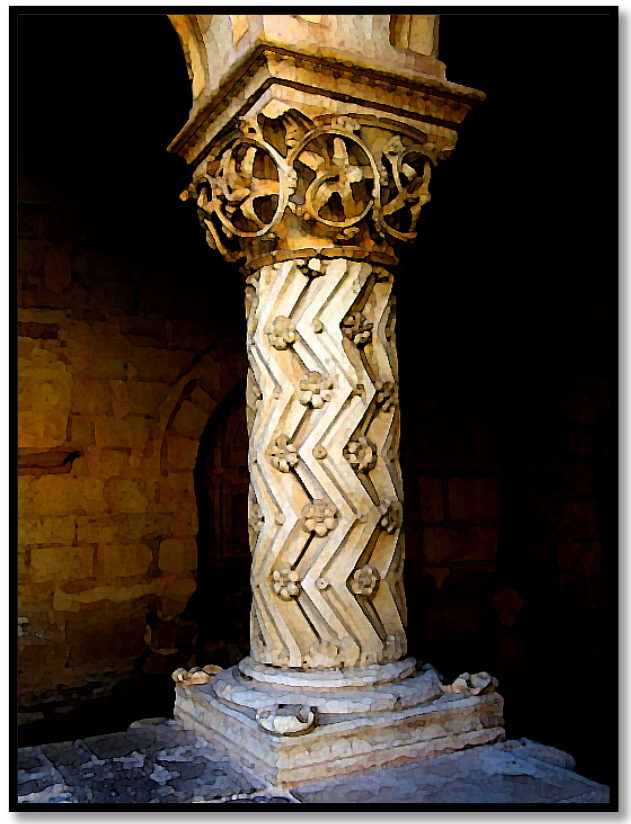

Columna de la iglesia de San Andrés del Arroyo, Palencia, España. Dibujo digital de Josué Pérez Sánchez. Febrero de 2016. 
En cuanto a las columnas serlianas, se pueden citar dos edificios barrocos de especial importancia: las de la portada lateral de la Catedral de San Luis Potosi ${ }^{56}$ y las de la portada principal del Santuario de Guadalupe (fundado en 1721), en el poblado del mismo nombre, ubicado en el actual Estado de Zacatecas ${ }^{57}$ (imagen 28).

Imagen 28

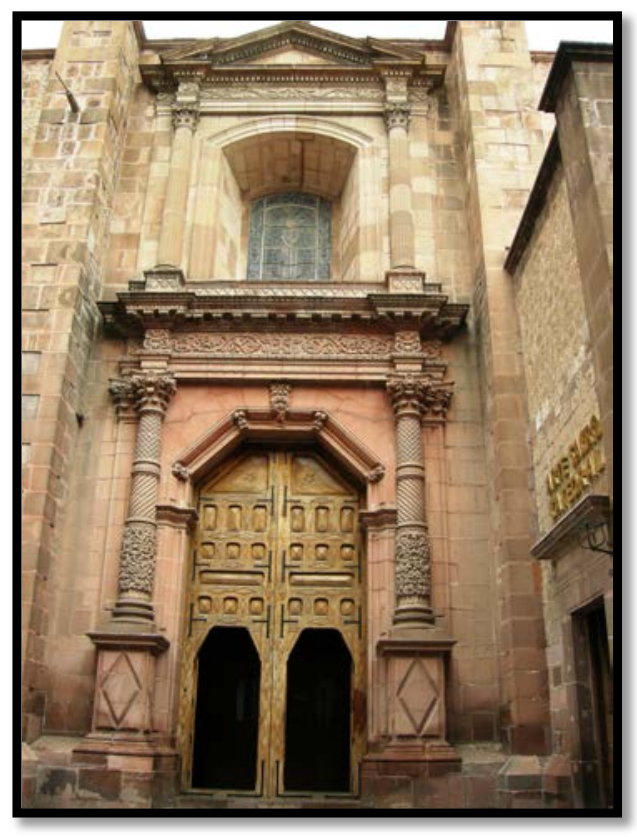

Portada lateral de la Catedral de San Luis Potosí, México. Foto: Martha Fernández.

De lo dicho, además de la importancia concedida a las columnas que flanqueaban el Templo de Salomón, es de destacarse nuevamente el retorno a fuentes medievales que, además de estar aparejado con el incentivo de los artistas por representar el Templo de Salomón con lenguajes tradicionales, también puede prestarse para plantear la hipótesis de que tal vez tuvieran la intención de tomar como modelo el trabajo de los francmasones medievales. $\mathrm{O}$ de otro modo: ¿acercarse incluso con elementos arquitectónicos a la cultura masónica?

\section{Algunos símbolos iconográficos}

A ello se agrega la presencia de símbolos iconográficos en la arquitectura barroca novohispana que, perteneciendo a otras tradiciones (cristianas o no) también pudieran tener una interpretación dentro de la cultura masónica. Así, por ejemplo, la representación de La

\footnotetext{
${ }^{56}$ La Catedral actual fue construida por el arquitecto Nicolás Sánchez Pacheco de 1703 a 1730, aunque es posible que las columnas de la portada lateral hayan pertenecido a la iglesia anterior, del siglo XVII.

${ }^{57}$ Fue fundada por fray Antonio Margil de Jesús. La iglesia se entrenó el año de 1721.
} 
Arquitectura, que se encuentra en un relieve de la fachada del palacio de los condes de Jaral de Berrio de la ciudad de México, mejor conocido como Palacio de Iturbide, construido por el arquitecto Francisco Antonio Guerrero y Torres de 1779 a 1785. Es importante su presencia como representación de una de las Artes Liberales; es decir, la Arquitectura reconocida ya como una actividad intelectual. En la obra aparecen la columna, la escuadra, el compás y la plomada, instrumentos de trabajo de los arquitectos y albañiles, que también han tenido una enorme importancia para la masonería, incluso en la actualidad (imagen 29).

La Arquitectura. Relieve de la fachada del Palacio de los condes de Jaral de Berrio, hoy Palacio de Iturbide de la ciudad de México. Foto: Martha Fernández.

Imagen 29

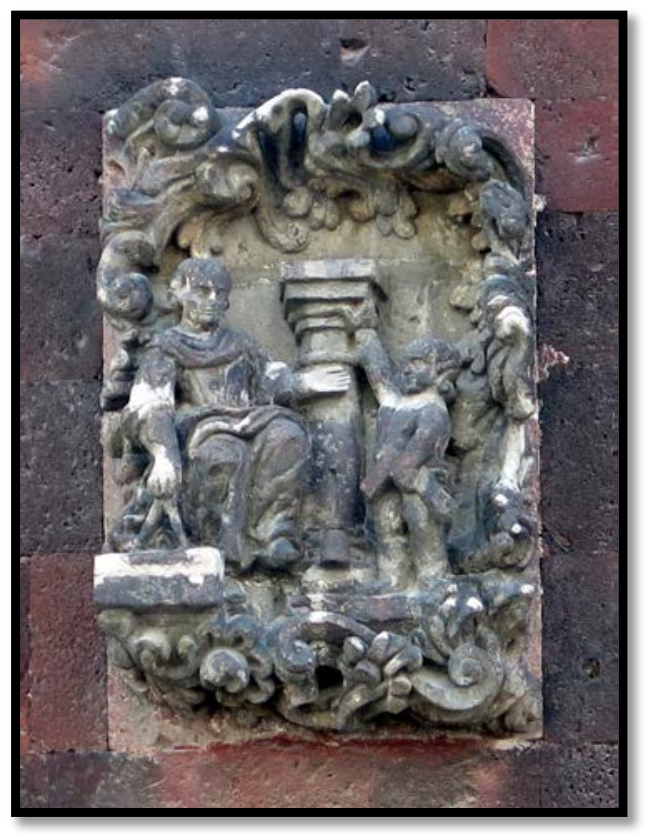

Igualmente, el "Ojo de Dios" o el "Ojo que todo lo ve" que se encuentra en el frontón de la portada de la iglesia de Nuestra Señora de Loreto de la ciudad de México, construida por el arquitecto Ignacio Castera y concluida el año de $1809^{58}$ (imágenes 30 y 31). Es una obra tardía, pero existen antecedentes en grabados y pinturas novohispanas en las que también aparece ese símbolo, como el que corona un grabado de Sylverio, que representa El Reloj de las Parcas, impreso en México el año de 1761, el cual sirvió de modelo a dos de las imágenes del Políptico de la Muerte, que se conserva en el Museo Nacional del Virreinato en Tepotzotlán, Estado de México ${ }^{59}$ (imagen 32). El ojo es un

\footnotetext{
58 Ana Lorenia García Martínez, "La vanguardia americana. Tradición arquitectónica novohispana y modelos importados en la arquitectura de la segunda mitad del siglo XVIII: El caso de la iglesia de Nuestra Señora de Loreto, Ciudad de México" (Tesis de Maestría en Historia del Arte, UNAM, 2005), 130.

59 Del Devocionario Reloj en modo de despertador (Méjico, 1761). Aunque el grabado sólo está firmado "Sylverio", es posible que se trate del grabador Francisco Silverio. Dato que debo y agradezco a la maestra Andrea Montiel. En la tesis citada, Rogelio Aragón Juárez nos informa que, en 1760, a Juan Pablo
} 
símbolo universal de percepción intelectual. De acuerdo con Juan Chevalier y Alain Gheerbrant, es un símbolo relacionado con el Sol y con el fuego ${ }^{60}$. Por su parte, Juan Carlos Daza explica que el

el ojo sin párpados, inscrito dentro de un triángulo, es un símbolo común a los cristianos, budistas, teósofos, antiguos egipcios, rosacruces y masones. Representa la penetración de la deidad en todo (la omnipresencia) y la imposibilidad de estar fuera de su campo de acción y visión, el Yo vigilante que al penetrar más allá de las apariencias descubre el sentido de la eternidad, de su realidad total y absoluta. Corresponde al ojo del corazón, por el cual el hombre ve a Dios, y Dios ve al hombre ${ }^{61}$.

\section{Imagen 30}

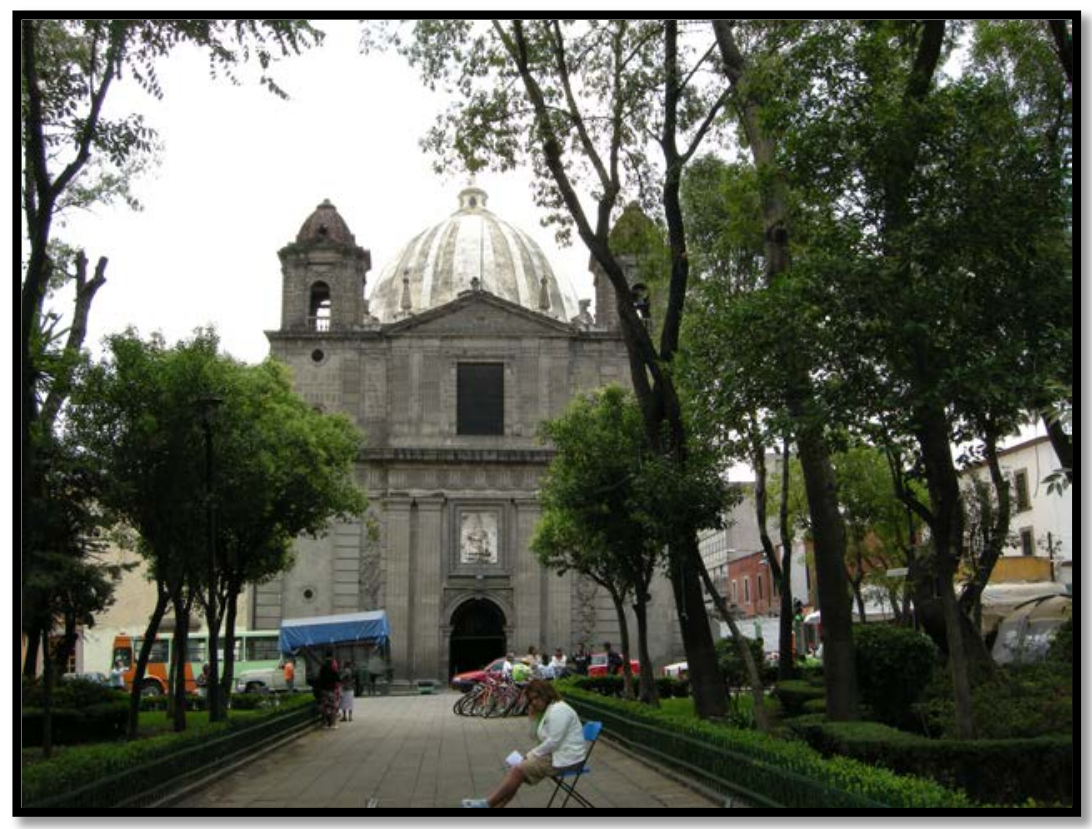

Iglesia de Nuestra Señora de Loreto de la ciudad de México. Foto: Martha Fernández.

Echegoyen, masón confeso asentado en Nueva España, le encontraron: un libro con "'Salomón, Juan Bautista, San Matheo con la excuadra de albañil en la mano, un hombre con un farol en la mano que lo llevaba cubierto y un ojo del Sol,' todas ellas imágenes de símbolos masónicos”. Aragón Juárez, "Contra la Iglesia y el Estado: Masonería e Inquisición en Nueva España, 1760-1820”, 63.

${ }^{60}$ Jean Chevalier y Alain Gheerbrant, Diccionario de los símbolos (Barcelona: Herder, 2007),770-774.

${ }^{61}$ Daza, Diccionario Akal de francmasonería, 281-282. 
Frontón de la iglesia de Nuestra Señora de Loreto, ciudad de México. Foto: Martha Fernández.

\section{Imagen 31}

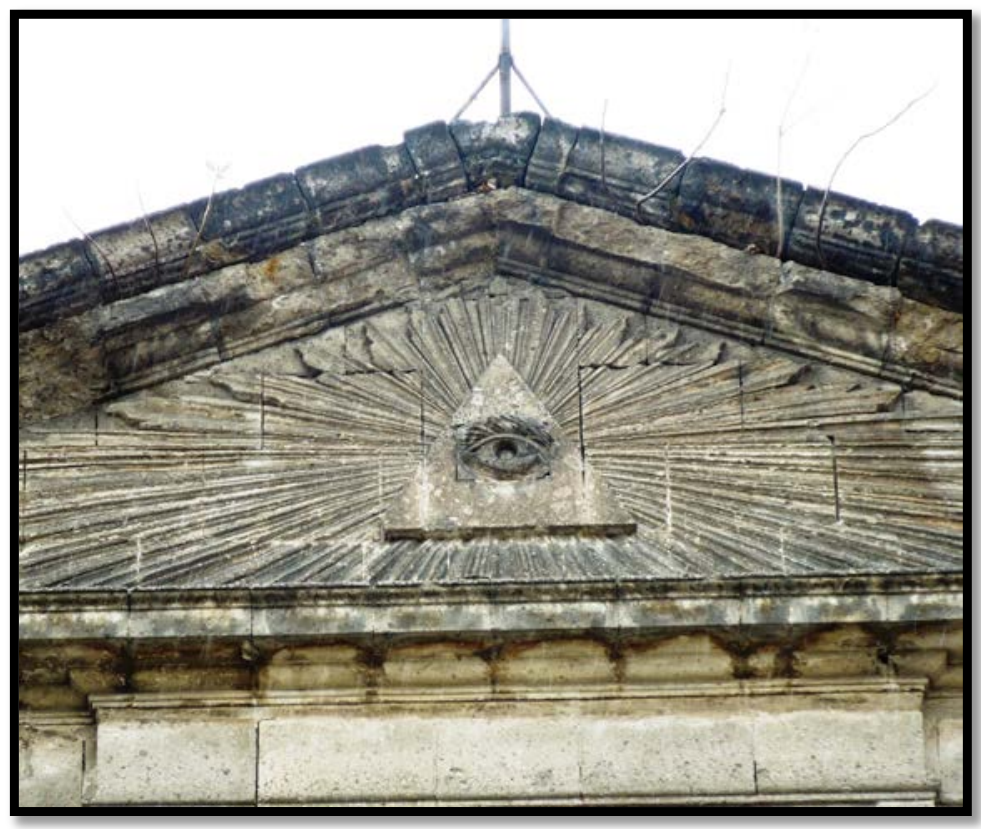

Imagen 32

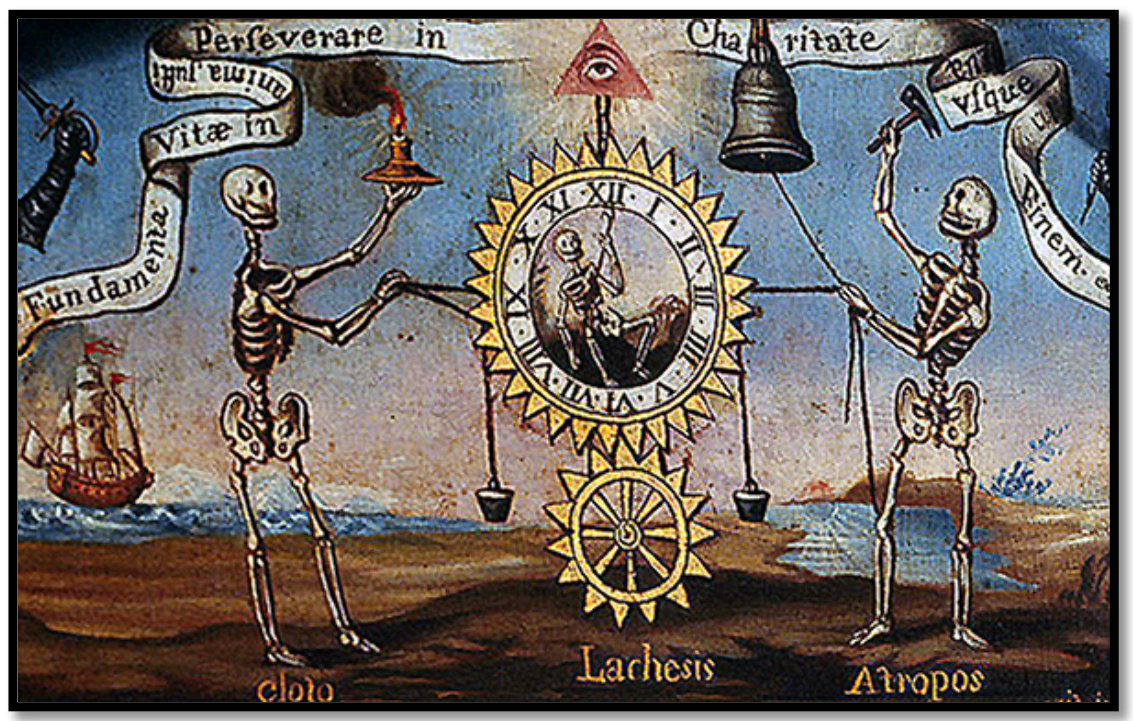

Anónimo: Políptico de la muerte, Museo Nacional del Virreinato, Tepotzotlán, México. Dibujo digital de Josué Pérez Sánchez. Febrero de 2016.

Asimismo, el remate de la portada de la iglesia del que fuera el hospital de San Juan de Dios de la ciudad de México, concluida por el arquitecto Miguel Custodio Durán en 1729, tiene literalmente espadas flamígeras con todo y empuñadura, coronadas por esferas (imágenes 33 y 34). En la tradición judeocristiana, la espada flamígera representa la que portaba el querubín que custodiaba el camino hacia el árbol de la vida en el paraíso terrenal, 
después de la expulsión ${ }^{62}$. La esfera, representa al mundo y la universalidad de la Iglesia católica; en los remates de muchas portadas y retablos novohispanos, Dios Padre está representado con una esfera en la mano, como se aprecia, por ejemplo, en la citada portada de la iglesia de El Carmen de San Luis Potosí. Igualmente, gran cantidad de portadas, torres y cúpulas, están rematadas por cruces que se apoyan en esferas. Si las asociáramos, además, con la tradición masónica, las espadas flamígeras podrían significar la Palabra de Dios y es el instrumento que otorga el poder espiritual al venerable maestro; mientras que las esferas, tal vez, significarían el mundo y con ello, la universalidad de la masonería ${ }^{63}$.

Imagen 33

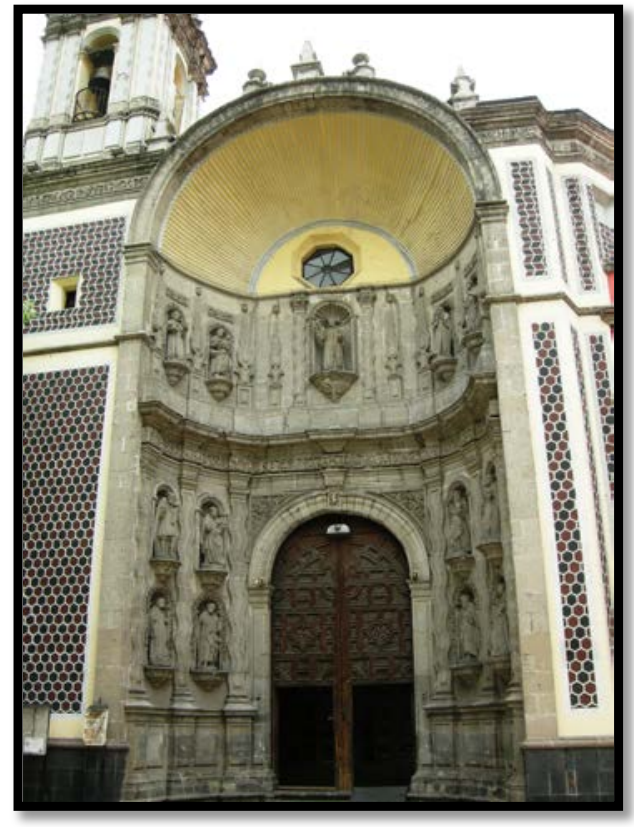

Portada principal de la iglesia de San Juan de Dios de la ciudad de México. Foto: Martha Fernández.
Imagen 34

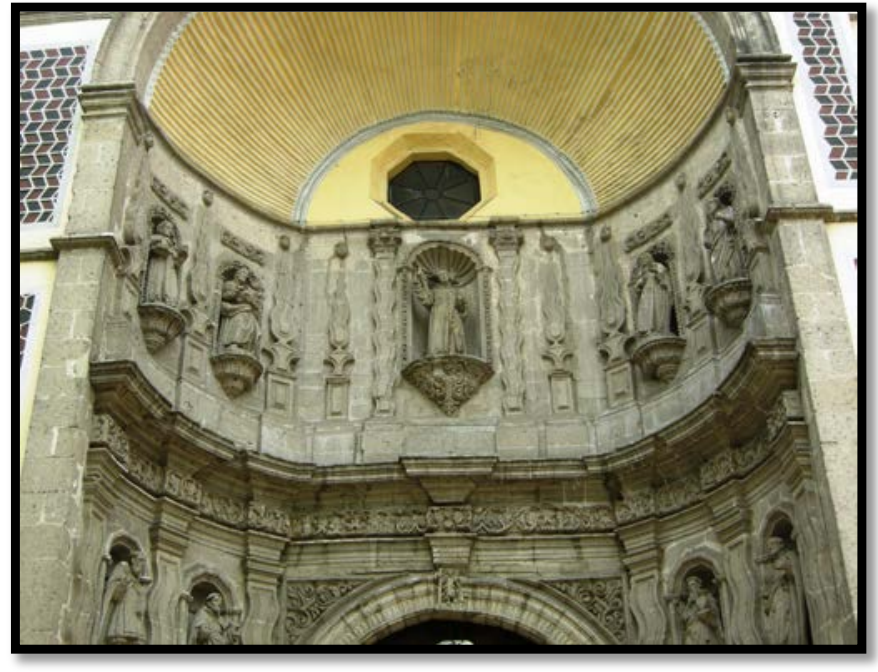

Remate de la portada principal de la iglesia de San Juan de Dios de la ciudad de México. Foto: Martha Fernández.

Algo parecido se aprecia en la portada de la capilla del Calvario o de Medina Picazo del templo de Regina, en la misma ciudad, construida igualmente por Miguel Custodio Durán en 1733 (imagen 35). Los dos soportes ondeantes son la imagen apilastrada de Jaquín y Bóaz, las legendarias columnas que flanqueaban el Templo construido por Salomón $^{64}$. Los remates, nuevamente, son espadas o dagas flamígeras, en este caso

\footnotetext{
${ }^{62}$ Génesis, 3:24.

${ }^{63}$ Debo aclarar que la simbología masónica la consulté básicamente en Daza, Diccionario Akal de la Francmasonería; W. Kirk MacNulty, Masonería. Símbolos, secretos, significado (Barcelona: Editorial Electa, 2006), y Christian Jacq, La masonería. Historia e iniciación (Madrid: Ediciones Martínez Roca, 2006).

${ }^{64}$ Ya hice referencia a las teorías de Guarino Guarini en este sentido.
} 
rematadas por el sol y la luna. Por su naturaleza, ambos son símbolos universales, aunque concretamente para el cristianismo, Jesús es el sol de justicia, anunciado por Malaquías cuando afirmó: "Mas para vosotros, los que teméis mi nombre, se alzará un sol de justicia que traerá en sus alas la salud", De ahí que en el Apocalipsis se afirme: "Yo, Jesús, envié a un ángel para testificaros estas cosas sobre las iglesias. Yo soy la raíz y el linaje de David, la estrella brillante de la mañana"66. La luna, por su parte, ha estado siempre relacionada con María, incluso en la Nueva España se vinculó con la Virgen de Guadalupe, como lo dejó ver Miguel Sánchez el año de 1648 en su obra titulada Imagen de la Virgen María Madre de Dios de Guadalupe, cuando al compararla con la Virgen del Apocalipsis, afirmó que la luna que tiene la imagen bajo sus pies, es la ciudad de México, "por lo natural fundada sobre aguas, en que predomina la luna"67. Es decir, que, en una interpretación cristiana, sobre los remates de la portada citada, estarían Cristo y la Virgen. ¿Pero si se tratara de una portada que estuviera asociada con la cultura masónica? En ese caso, tendríamos que recordar que, para los masones, el Sol es la columna del sur, lugar de los maestros, y la Luna, es la del norte, donde trabajan los aprendices. Corona la composición una cruz de doble travesaño, muy frecuente en la Nueva España, que podría tratarse de una cruz patriarcal, del patriarca de Jerusalén, lo que no sería nada extraño en vista del interés salomonista presente en la cultura novohispana desde el siglo XVI.

\footnotetext{
${ }^{65}$ Malaquias, 4:2.

${ }_{67}^{66}$ Apocalipsis, 22:16.

${ }^{67}$ Miguel Sánchez, Imagen de la Virgen María Madre de Dios de Guadalupe. Milagrosamente aparecida en la ciudad de México. Celebrada en su historia, con la profecía del capitulo doce del Apocalipsis, en: Ernesto de la Torre Villar y Ramiro Navarro de Anda, Testimonios históricos guadalupanos, 2a ed. (CDMX: Fondo de Cultura Económica, 1999), 167.
} 
Imagen 35

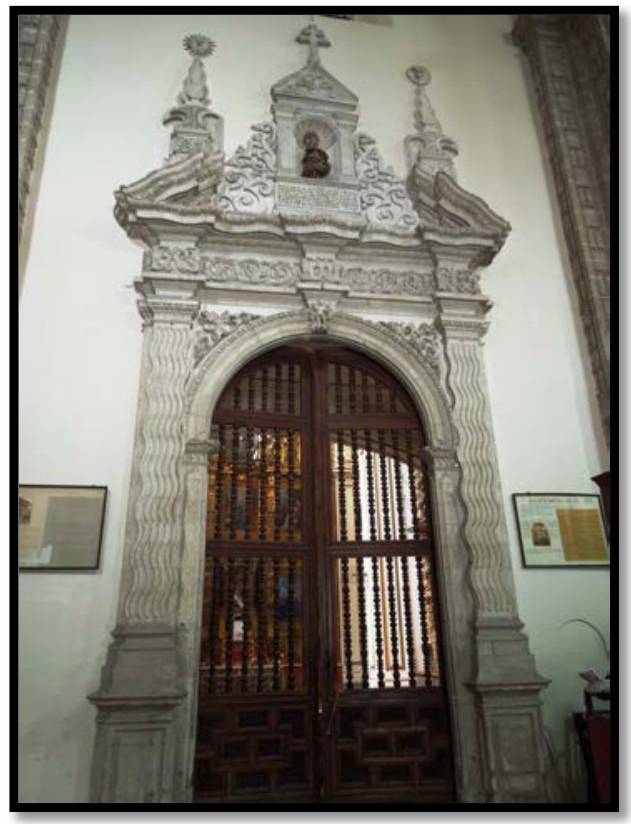

Portada de la capilla del Calvario o de Medina Picazo de la iglesia de Regina, ciudad de México. Foto: Martha Fernández.

Sobre los remates piramidales de la portada de Porciúncula de la iglesia franciscana de Santiago Tuxpan, en Michoacán (hoy parroquia), construida por el arquitecto Pedro de Arrieta hacia el año de 1716, se encuentra un elemento enigmático que consiste en un paño anudado al centro, del que salen cuatro puntas a manera de cruz griega (imágenes 36 y 37). [Fotos 36-37] Es difícil deducir su significado, pero me llamó la atención una explicación de Juan Carlos Daza respecto a los Santos Coronados y que -pienso- tal vez podría aplicarse a esta pieza. Para los masones, dice, los Cuatro Santos Coronados

figuran en las cuatro ramas de la cruz de los elementos, en cuyo centro está la quintaescencia, representan los cuatro 'regentes', los 'cuatro polos terrestres', por encima de los cuales está el polo Supremo, el eje central a cuyo alrededor giran las ramas de la esvástica, símbolo de la manifestación dinámica. Arconte de las cuatro direcciones cardinales, se afirman como los rectores de toda orientación justa y regular. En este sentido son los verdaderos inspiradores ocultos de los compañeros constructores ${ }^{68}$.

Tampoco se puede descartar, sin embargo, que ese elemento pudiera ser que se tratara de un símbolo Rosacruz.

\footnotetext{
${ }^{68}$ Daza, Diccionario Akal de la francmasonería, 338.
} 


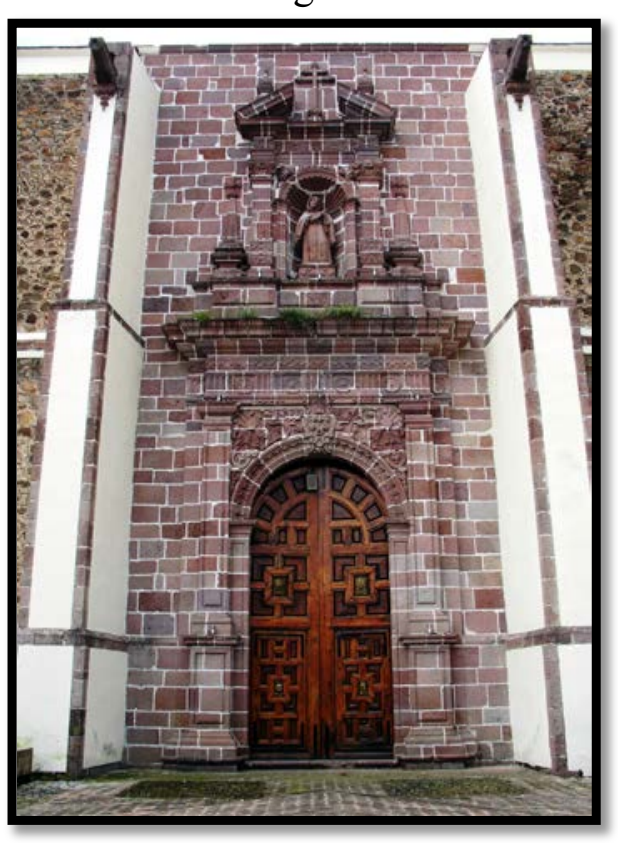

Portada de Porciúncula de la iglesia franciscana de Santiago, Tuxpan, Michoacán. (Hoy parroquia). México. Foto: Martha Fernández.
Imagen 37

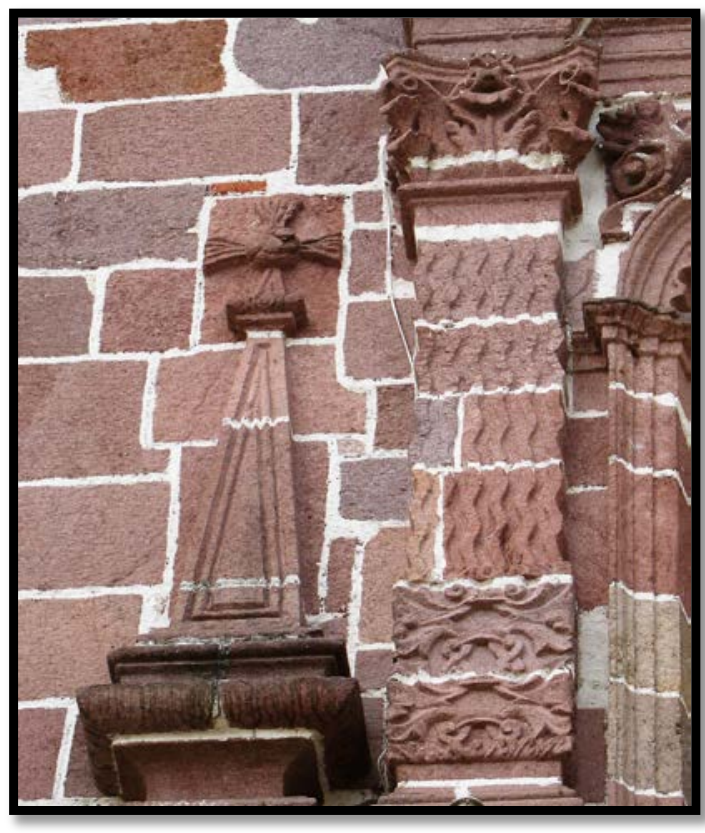

Uno de los remates de la portada de Porciúncula de la iglesia franciscana de Santiago, Tuxpan, Michoacán. (Hoy parroquia). Foto: Martha Fernández.

Las pirámides sobre las que se asientan esas enigmáticas piezas, por su parte, son símbolos universales utilizados por todas las culturas y que tienen múltiples significados relacionados básicamente con la ascencionalidad y la convergencia ${ }^{69}$. También representan la Montaña Sagrada o Monte del Mundo, que tuvo una enorme importancia para la cultura judeocristiana $^{70}$, porque las montañas "son el vínculo por excelencia entre la tierra y el cielo", como explica Mircea Eliade ${ }^{71}$. Por ello, los textos escriturarios mencionan varias montañas sagradas: después del Diluvio, "el día veintisiete del séptimo mes", el arca de Noé, la de la salvación, "se asentó ... sobre los montes de Ararat" "72 y fue ahí donde surgió la nueva humanidad. Fue en el monte Sinaí, donde Yahvé le entregó a Moisés las tablas de la Ley, la Torá ${ }^{73}$. En la vida de Jesús, las montañas tuvieron una gran importancia: en el monte de las Bienaventuranzas, dictó la carta magna del Reino de los Cielos ${ }^{74}$; en el monte Tabor tuvo lugar su transfiguración ${ }^{75}$; en el Gólgota murió ${ }^{76}$, y desde el Monte de los

\footnotetext{
${ }^{69}$ Chevalier y Gheerbrant, Diccionario de los símbolos, 837-839.

${ }^{70}$ De Champeaux y Sterckx, Introducción a los símbolos, 223-224.

${ }^{71}$ Mircea Eliade, Lo sagrado y lo profano (Barcelona: Paidós, 1998), 34.

72 Génesis, 8:4.

${ }^{73}$ Éxodo, 16:20.

${ }^{74}$ Mateo, 1:1-11.

${ }^{75}$ Mateo, 17:1-2.

${ }^{76}$ Marcos, 15:22-26; Mateo, 27:33-38; Juan, 19:17-20.
} 
Olivos ascendió a los cielos ${ }^{77}$. Por su parte, Juan declaró que, para mostrarle la Jerusalén Celestial, el ángel lo "trasladó en espíritu a un monte grande y alto"78. Pero también tienen un significado importante en la tradición masónica, pues las pirámides son la piedra filosofal, emblema de la construcción, sobre la que se ejercitan los maestros masones.

En varios edificios de la ciudad de México, encontramos también la formación de cadenas a base de molduras. Entre las más evidentes se encuentran las del friso del Santuario de Nuestra Señora de Guadalupe, que finalmente construyó el arquitecto Pedro de Arrieta de 1695 a 1709 (imágnes 38 y 39), así como las que invaden la fachada del citado palacio de Iturbide (imagen 40). Las cadenas, en general, representan la unión entre el cielo y la tierra; Homero relata que cuando Zeus tonante pidió sumisión a los dioses, les dijo:

Ya si queréis, haced esta prueba, oh dioses, para que os convenzáis. Suspended del cielo áurea cadena, asíos todos, dioses y diosas, de la misma, y no os será posible arrastrar del cielo a la tierra a Júpiter, árbitro supremo, por mucho que os fatiguéis, mas si yo me resolviese a tirar de aquélla, os levantaría con la tierra y el mar, ataría un cabo de la cadena en la cumbre del Olimpo, y todo quedaría en el aire. Tan superior soy yo a los dioses y a los hombres ${ }^{79}$.

Imagen 38

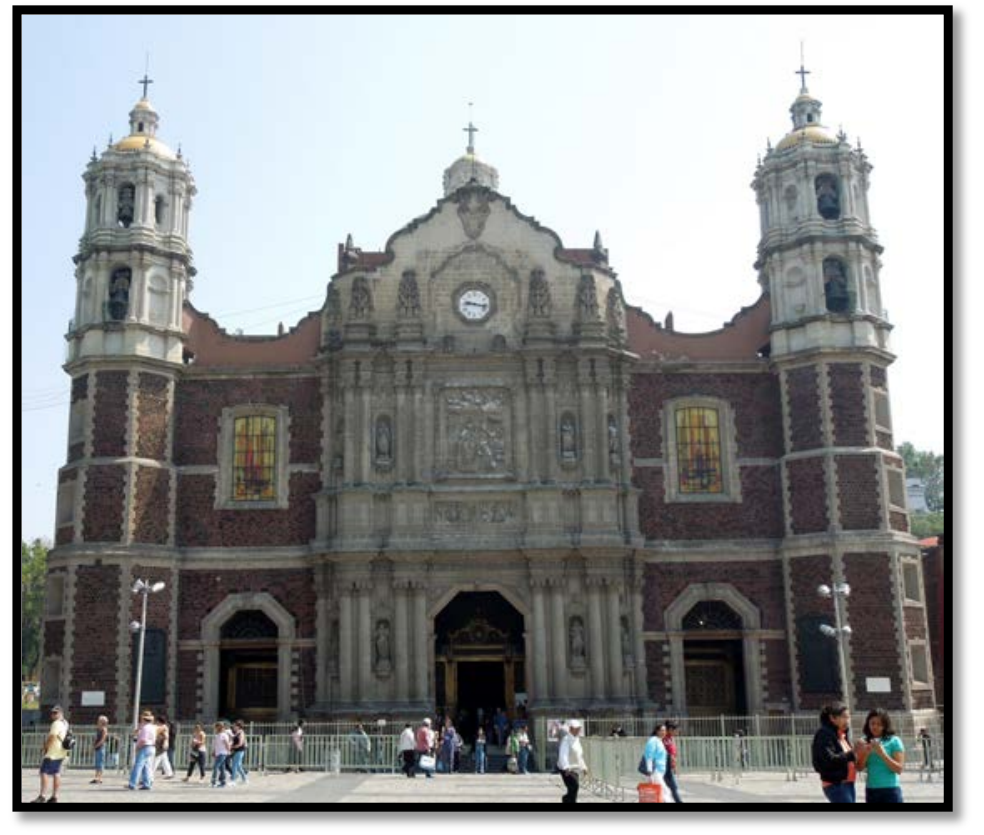

Fachada del Santuario de Nuestra Señora de Guadalupe de la ciudad de México. Foto: Martha Fernández.

\footnotetext{
${ }^{77}$ Marcos, 16:19; Lucas, 24:50-51; Hechos, 1:6-11.

${ }^{78}$ Apocalipsis, 21:10.

${ }^{79}$ Homero, La Ilíada (México: Editorial Porrúa, 1969), canto VIII, 5-27.
} 
Molduras en forma de cadena que decoran el friso del primer cuerpo de la portada principal del Santuario de Nuestra Señora de Guadalupe de la ciudad de México. Foto: Martha Fernández.

Imagen 39

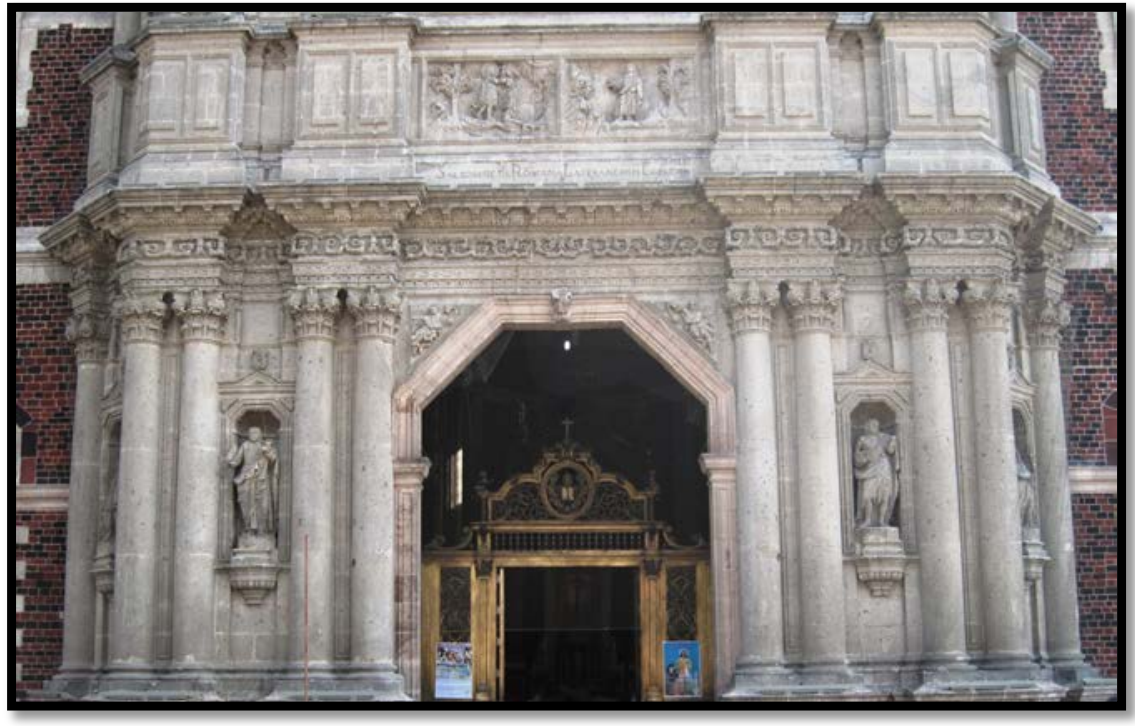

\section{Imagen 40}

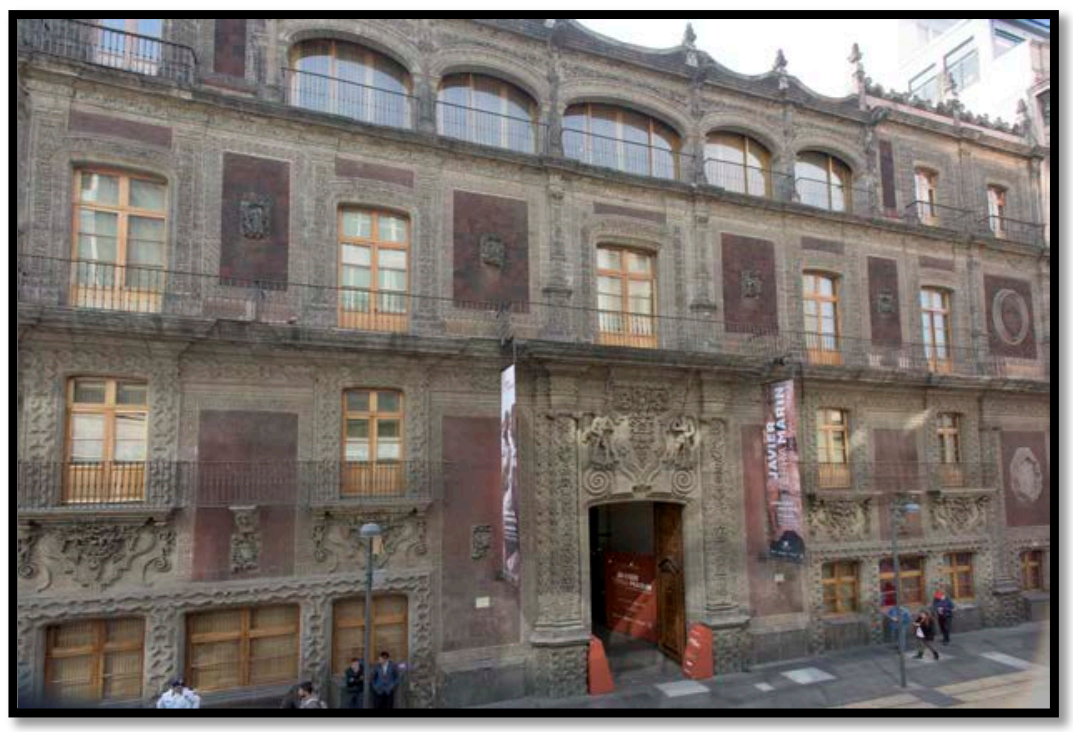

Fachada del palacio de los condes de Jaral de Berrio o Palacio de Iturbide de la ciudad de México. Foto: Gerardo Vázquez Miranda. Archivo Fotográfico "Manuel Toussaint", IIE, UNAM.

Para la masonería, las cadenas son símbolo de Unión de la fraternidad ¿no podría ser también éste, el simbolismo que tengan las cadenas en las obras novohispanas?

No faltan, tampoco, águilas bicéfalas, como las que se abren a lo largo de la fachada de la iglesia del ex convento de Santa Mónica de Guadalajara, fundado el año de 1720 a instancias del padre jesuita Feliciano Pimentel ${ }^{80}$ (imágenes 41 y 42). El águila como

\footnotetext{
${ }^{80}$ Aunque el fundador fue un padre jesuita, las monjas que lo habitaron adoptaron la regla de San Agustín, a solicitud del obispo de Puebla Manuel Fernández de Santa Cruz.
} 
símbolo solar, se relaciona con Cristo, pero su historia es larga en diversos pueblos de la antigüedad. Fue adoptado como símbolo por los turcos en la Edad Media y transmitido a los cristianos en el tiempo de las Cruzadas, para ser adoptadas por casas imperiales como la de los Austrias. De acuerdo con Jean Chevalier y Alain Gheerbrant, las dos cabezas inclinadas, refuerzan el simbolismo mismo del águila: “autoridad más que regia, soberanía verdaderamente imperial, rey de reyes" ${ }^{\text {" }}$. Si tomamos en cuenta que el convento de Santa Mónica de Guadalajara fue fundado cuando ya reinaba en España la casa de los Borbón, obviamente las águilas bicéfalas no harían referencia a la casa reinante; por ello, podríamos pensar en otro simbolismo, ¿alguno vinculado con la masonería? Para esas agrupaciones, las águilas bicéfalas representan la sabiduría potenciada y es emblema del grado 33 del Rito Escocés $^{82}$.

Imagen 41

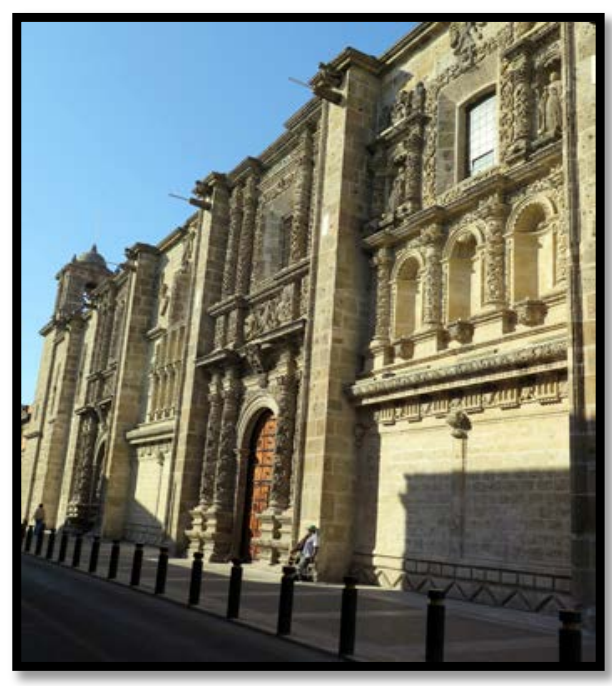

Fachada de la iglesia de Santa Mónica de la ciudad de Guadalajara, Jalisco, México. Foto: Martha Fernández.
Imagen 42

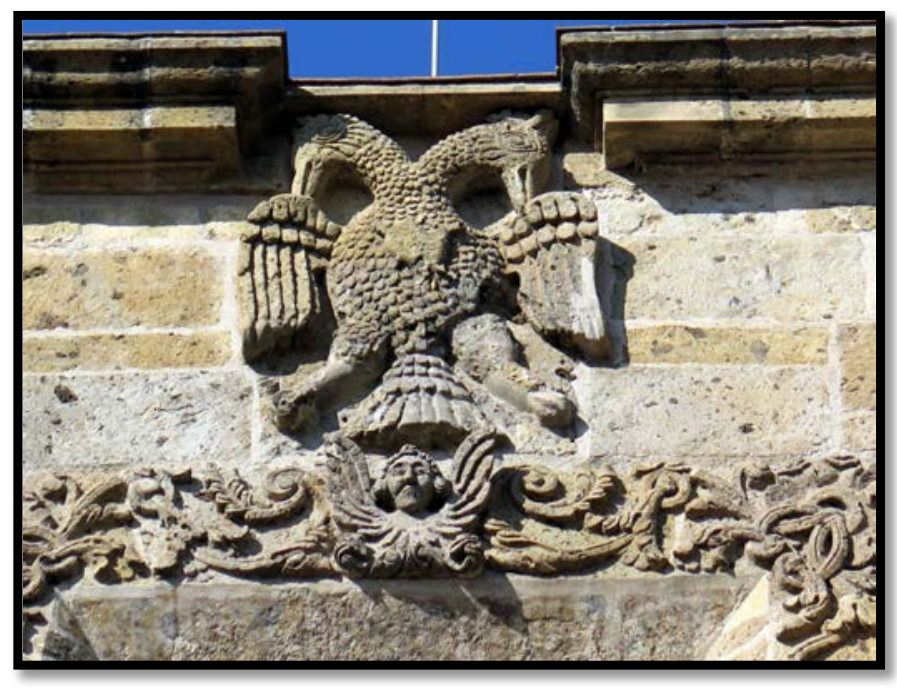

Detalle de la fachada de la iglesia de Santa Mónica de la ciudad de Guadalajara, Jalisco, coronado por un águila bicéfala. Foto: Martha Fernández.

\section{El retrato de un arquitecto}

A todo lo dicho, agrego un dato más (imagen 43). Las esculturas que se encuentran repartidas en las cinco portadas exteriores más importantes de la Catedral de México (la del Perdón, las procesionales y las del crucero) representan, en conjunto, a los doce apóstoles; entre ellos, en el primer cuerpo de la portada poniente del crucero, aparentemente se encuentra Santo Tomás, arquitecto de profesión que suele representarse con una escuadra

\footnotetext{
${ }^{81}$ Chevalier y Gheerbrant, Diccionario de los simbolos, 64-65.

${ }^{82}$ Daza, Diccionario Akal de la francmasonería, 21.
} 
en la mano. No obstante, la efigie que se localiza en el templo metropolitano no tiene solamente la escuadra, sino también el compás, símbolos que sostiene con la mano derecha (imagen 44). Se trata, sin duda, del retrato de un arquitecto, que nos recuerda los retratos de los maestros masones europeos que aparecen sosteniendo sus instrumentos de trabajo, como los del maestro Anton Pilgram, en la Catedral de San Esteban de Viena.

Imagen 43

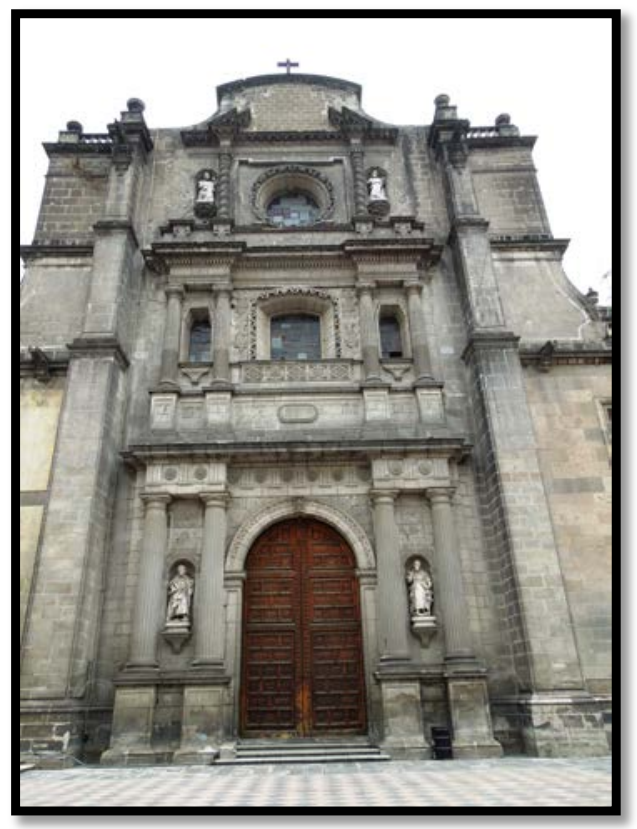

Portada poniente del crucero de la Catedral de México, ciudad de México. Foto: Martha Fernández.

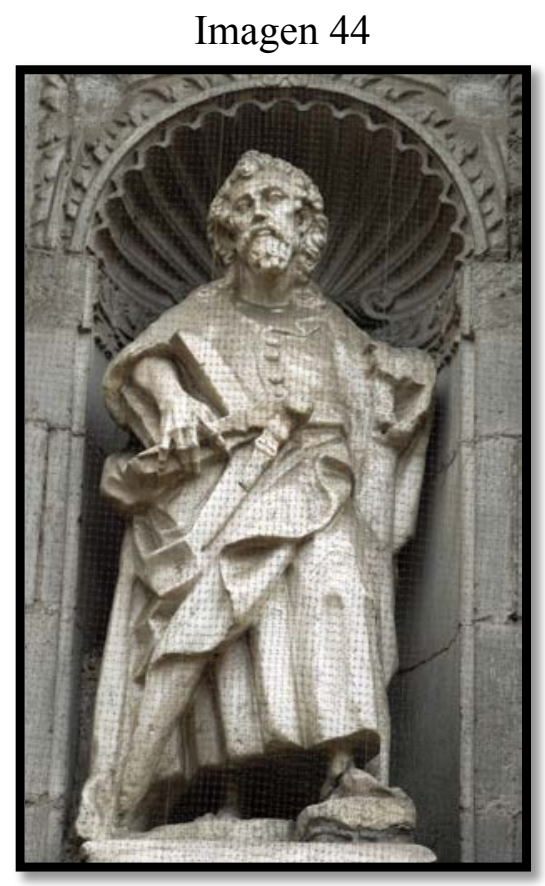

Retrato de un arquitecto, localizado en el nicho norte (izquierdo) del primer cuerpo de la portada poniente del crucero de la Catedral de México. Foto: Martha Fernández.

Como el retrato de la Catedral de México está mutilado, no es imposible conocer su identidad -al menos por el momento-. Podría tratarse del maestro mayor Cristóbal de Medina Vargas, quien edificó las portadas del crucero de la Catedral entre 1688 y 1689; aunque también podría ser el arquitecto Pedro de Arrieta, quien igualmente fue maestro mayor de la Catedral de 1720 a 1738 y -como vimos- estuvo muy activo en la modernización del gremio. De cualquier manera, estaríamos entre finales del siglo XVII y principios del siglo XVIII, época en la que Christopher Wren "el último gran Maestro de la antigua masonería" construía la catedral de San Pablo de Londres (1676-1710), "la última obra masónica tradicional", como afirma Christian Jacq ${ }^{83}$.

\footnotetext{
${ }^{83}$ Jacq, La masonería, 137.
} 
Pero también fueron tiempos de la formación de las primeras logias especulativas de España y Estados Unidos, como referimos anteriormente. Nada de esto pudo escapar a la sociedad novohispana del siglo XVIII y también tendríamos que vincular esta información con el hecho de que la primera reforma a las Ordenanzas planteadas por Pedro de Arrieta y otros arquitectos, datan del año de 1735; es decir, siete años después de la fundación de la primera logia masónica especulativa de España y dos después de que se fundara la norteamericana. Todo ello, dentro del ambiente ilustrado en el que se desenvolvieron los artistas de la Nueva España y su necesidad de defender su propia identidad, su "Ilustración novohispana".

\section{Reflexiones finales}

Es difícil llegar a conclusiones en una investigación que apenas está esbozada en esta reunión de hechos y conjeturas. Quizá solamente pueda permitirme enlistar algunos de los indicios más sugerentes que tal vez nos permitieran relacionar el arte barroco del México virreinal, con una posible aproximación con la cultura masónica.

Lo primero, el acercamiento que tuvieron los diferentes gremios de artistas a algunos conceptos como el de El Gran Arquitecto del Universo y los Santos Coronados; estos últimos, vinculados exclusivamente a ellos. El retorno a las fuentes del arte medieval, quizá como una manera de acercarse al trabajo de los francmasones. La reconstrucción del Templo de Salomón con características que evocan la Tienda del Maestro Masón.

Se podría pensar que, al formar agrupaciones, posiblemente masónicas (o semejantes a ellas), los artistas hayan pretendido reorganizar su trabajo y llevarlo a la categoría efectiva de Arte Liberal; ciertamente a la manera antigua de los artistas medievales, pero para llegar a la modernidad ilustrada de su tiempo. En ese sentido habría que profundizar más, pero las bases filosóficas de la Ilustración debieron ser muy importantes para presentar esos indicios que conducen a pensar en un posible acercamiento a la cultura masónica, con apoyo y participación de la sociedad novohispana, pese a las prohibiciones establecidas por la Corona y la Iglesia. No puede ser gratuito, por ejemplo, que desde finales del siglo XVII, retratos de Sor Juana Inés de la Cruz (1651-1695), símbolo de la intelectualidad novohispana, por antonomasia, representen a la monja escritora, con la escuadra y el compás, como el que se realizó en España, todavía en vida de ella, para el frontispicio del Segundo Volumen de sus Obras, editado en Sevilla, el año de 1692 (imagen 45). 


\section{Imagen 45}

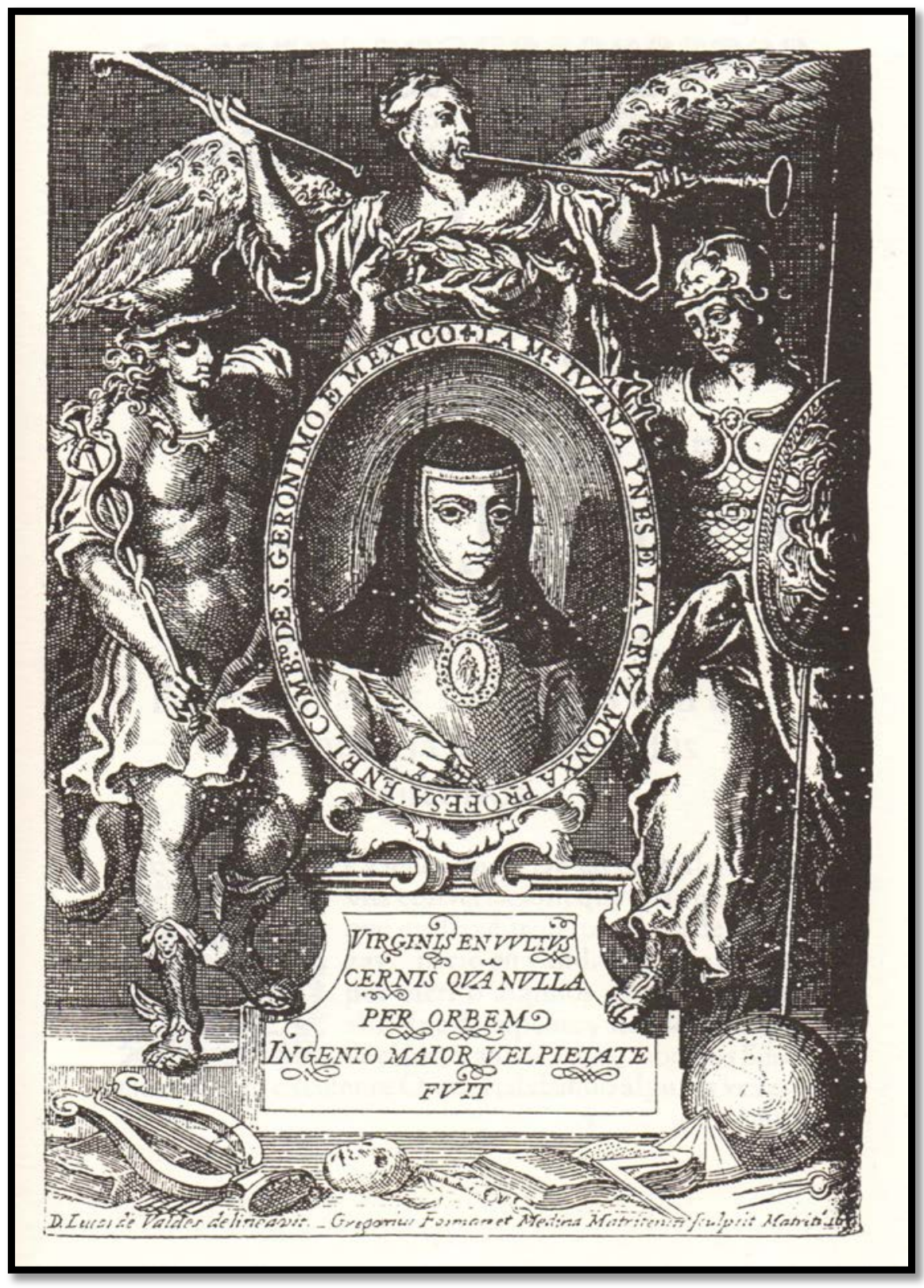

Retrato de Sor Juana Inés de la Cruz con la escuadra y el compás. Frontispicio del Segvndo volvmen de las Obras de Soror Jvana Ines de la Crvz, monja profesa en el monasterio del Señor San Geronimo de la Civdad de Mexico, dedicado por sv misma avtora A D. Juan de Orue y Arbieto Cavallero de la Orden de Santiago, Año 1692. Con privilegio, En Sevilla, por Tomas Lopez de Haro, Impressor, y Mercader de Libros. Foto tomada de: Sor Juana Inés de la Cruz: Segundo volumen de sus obras, edición facsimilar, introducción de Margo Glantz, 2a ed., México, CDMX, UNAM, Facultad de Filosofía y Letras, 2010. El dibujo del retrato fue realizado por el pintor sevillano Lucas Valdés y el grabado por el madrileño Gregorio Fosman y Medina. Reprografía: Martha Fernández. 
Ya en el siglo XVIII, la organización de este tipo de agrupaciones, bien pudo ser una forma de defenderse de la irrupción de las Reformas Borbónicas, que desde el principio mostraron la necesidad de cambiar la organización gremial y procurar una mayor y mejor preparación de los artistas. De hecho, verbigracia, desde principios del siglo XVIII comenzaron a llegar a la Nueva España ingenieros militares que, en teoría, se encontraban mejor preparados para emprender la construcción de los edificios que más importaban a la corona de España, lo que de inmediato puso en alerta a los arquitectos novohispanos.

Los elementos iconográficos que podemos encontrar tanto en iglesias como en palacios, que tal vez puedan prestarse a una lectura vinculada con la masonería, nos indican igualmente la presencia de la nobleza y de la alta burguesía de la Nueva España, como se manifiesta en la iconografía del palacio de los condes de Jaral de Berrio, en la de la iglesia de Nuestra Señora de Loreto de la ciudad de México, cuya construcción fue patrocinada por el conde de Basoco; en la portada de la capilla del Calvario de la iglesia de Regina, de la misma ciudad capital, financiada por el rico comerciante Ventura de Medina Picazo y en los raros símbolos que rematan la portada lateral de la iglesia de Santiago Tuxpan, cuya edificación fue promovida por los condes de Miravalle. También parte del clero pudo tener cierta participación en ello (pese, insisto, a las prohibiciones), porque parece poco creíble que en plena Catedral Metropolitana de México se haya colocado el retrato de un arquitecto con la escuadra y el compás, sin el conocimiento y la autorización previos del arzobispo y del propio Cabildo.

Por lo mismo, parece factible pensar que para artistas y sociedad, la cultura masónica o agrupaciones parecidas a las masónicas, quizás también pudieron haber significado algo mucho más importante: un elemento integrador de unidad para manifestar

y defender su identidad, la identidad criolla, que caracterizó a la Nueva España, muy especialmente durante el desarrollo de la cultura barroca del siglo XVIII, como se manifiesta en la defensa de su propia tradición en las teorías artísticas desarrolladas en esa época, base central de lo que he llamado "Ilustración novohispana".

\section{Bibliografía}

Aragón Juárez, Rogelio. "Contra la Iglesia y el Estado: Masonería e Inquisición en Nueva España, 1760-1820”. Tesis de Licenciatura en Historia, Universidad del Instituto Helénico, México, 2006.

Architectura mecánica conforme a la práctica de esta ciudad de México. Fondo Reservado de la Biblioteca Nacional de México.

Bazarte Martínez, Alicia y Clara García Ayluardo. Los costos de la salvación, las cofradías y la ciudad de México (siglos XVI al XIX). México, CDMX: CIDE, IPN, AGN, 2001. 
Bermúdez de Castro, Diego Antonio. Theatro Angelopolitano o Historia de la ciudad de la Puebla, ed. Facsimilar. Puebla: Junta de Mejoramiento Moral, Cívico y Material del Municipio de Puebla, 1985. [1 ${ }^{\mathrm{a}}$ ed.: 1746].

Burke, Markus B. "The Five Pannonian Masons as Woodcarvers". Treasures of Mexican Colonial Painting. Davenport: The Davenport Museum of Art, 1998.

Champeaux, Gerard de y Dom Sébastien Sterck. Introducción a los símbolos. Traducción de Abundio Rodríguez, O. S. B. Madrid: Ediciones Encuentro, 1992.

Chevalier, Jean y Alain Gheerbrant: Diccionario de los símbolos. Traducción de Manuel Silvar y Arturo Rodríguez. Barcelona: Herder, 2007.

Daza, Juan Carlos, Diccionario Akal de la francmasonería. Madrid: Ediciones Akal, 1997.

Devocionario Reloj en modo de despertador. Méjico, 1761. Fondo Reservado de la Biblioteca Nacional de México.

Eliade, Mircea: Lo sagrado y lo profano. Traducción de Luis Gil Fernández. Barcelona: Paidós, 1988.

Fernández, Martha. Arquitectura y gobierno virreinal. Los maestros mayores de la ciudad de México. Siglo XVII. México, CDMX: UNAM, Instituto de Investigaciones Estéticas, 1985.

Fernández, Martha. Cristóbal de Medina Vargas y la arquitectura salomónica en la Nueva España durante el siglo XVII. México, CDMX: UNAM, Instituto de Investigaciones Estéticas, 2002.

Fernández, Martha. La imagen del Templo de Jerusalén en la Nueva España. México, CDMX: UNAM, Coordinación de Humanidades, 2003.

Fernández, Martha. Estudios sobre el simbolismo en la arquitectura novohispana. México, CDMX: UNAM, Instituto de Investigaciones Estéticas, INAH, 2011.

Fernández, Martha. "El arte: de la Ilustración novohispana a la Ilustración en México” para El arte en tiempos de cambio. 1810-1910-2010. México, CDMX: UNAM, Instituto de Investigaciones Estéticas, 2012.

Fernández de Echeverría y Veytia, Mariano. Historia de la fundación de la ciudad de la Puebla de los Ángeles en la Nueva España, su descripción y presente estado, 2 v., $2^{\mathrm{a}}$ ed. Prólogo y notas de Efraín Castro Morales. Puebla: Ediciones Altiplano, 1962 (Fuentes para la Historia de Puebla: I). [Escrita en 1780].

Ferrer Benemeli, José Antonio. La masonería española en el siglo XVIII. Madrid: Siglo XXI de España Editores, 1974.

Ferrer Benemeli, José Antonio. La masonería española. Madrid: Ediciones Itsmo, 1996.

Gamiño Ochoa, Rocío. Alexandro de la Santa Cruz Talabán. Un tratado artístico y científico inédito, 1778. México, CDMX: UNAM, Instituto de Investigaciones Estéticas, 2012. 
García Martínez, Ana Lorenia. "La vanguardia americana. Tradición arquitectónica novohispana y modelos importados en la arquitectura de la segunda mitad del siglo XVIII: El caso de la iglesia de Nuestra Señora de Loreto, Ciudad de México”. Tesis de Doctorado en Historia del Arte, Universidad Nacional Autónoma de México, 2005.

Goycoechea, Juan de. La maravilla inmarcesible, y milagro continuado de María Santíssima Señora Nuestra, en su prodigiosa imagen de Guadalupe de México. Compite firmezas con su nuevo Templo, que la copia: adelanta duraciones al Cielo, que a su Efigie traslada; iguala permanencias con el Augusto Sacramento, de quien imita la Milagrosa Presencia en su Pintura. Reproducido en Nueve Sermones Guadalupanos (1661-1758). Selección y estudio introductorio de David A. Brading. México, CDMX: Centro de Estudios de Historia de México Condumex, 2005.

Guarini, Guarino. Architettura civile. Introducción de Nino Carboneri. Notas y apéndices de Bianca Tavessi La Greca. Milán: Edizioni il Polifilo, 1968 [1ª ed., 1737].

Homero. La Ilíada. $10^{\circ}$ ed. Traducción de Luis Segala y Estalella. Prólogo de Alfonso Reyes. México: Editorial Porrúa, 1969.

Jacq, Christian. La masonería. Historia e iniciación. Madrid: Ediciones Martínez Roca, 2006.

Márquez, Pedro José. Sobre lo bello en general. Discurso, s/1, Oficina del Diario, 1801. Pedro José Márquez. Sobre lo bello en general y dos monumentos de arquitectura mexicana: Tajín y Xochicalco. Estudio y edición de Justino Fernández. México, CDMX: UNAM, Instituto de Investigaciones Estéticas, 1972.

Márquez, Pedro José. Dell'Ordine Dórico. Ricerche didicate alla reale Academia di S. Luigi di Zaragoza da Pietro Márquez, messicano. Con apéndice sopra Una antica tavola di Pozzuolo. Roma: presso il Salomón, 1803.

MacNulty, W. Kirk. Masonería. Símbolos, secretos, significado. Barcelona: Editorial Electa, 2006.

Moyssén, Xavier. "La primera Academia de Pintura en México". Anales del Instituto de Investigaciones Estéticas 34 (1965).

Olvera Calvo, María del Carmen. "La biblioteca de un arquitecto de la época virreinal en México". Boletín Monumentos Históricos 6 (1981).

Olvera Calvo, María del Carmen y Ana Eugenia Reyes y Cabañas. "El gremio y la cofradía de los canteros de la Ciudad de México". Boletín de Monumentos Históricos 2 (2004).

Ramírez Montes, Mina, "En defensa de la pintura. Ciudad de México, 1753”. Anales del Instituto de Investigaciones Estéticas 78 (2001).

Reyes y Cabañas, María Eugenia. "Las ordenanzas de arquitectura de la ciudad de México de 1735". Boletín de Monumentos Históricos 1 (2004). 
Sagrada Biblia. Versión directa de las lenguas originales por Eloíno Nácar Fuster y Alberto Colunga, O. P. Madrid: Biblioteca de Autores Cristianos, 1964.

Santiago Silva, José de. Apéndice documental. Atotonilco. Alfaro y Pocasangre. Guanajuato: Ediciones La Rana, 2004.

Serlio, Sebastián. Todas las obras de arquitectura y perspectiva de Sebastián Serlio de Bolonia. Introducción "La fortuna de Sebastián Serlio" por Carlos Sambricio. Estudio lingüístico y edición castellana al cuidado de Fausto Díaz Padilla. Oviedo: Colegio Oficial de Aparejadores y Arquitectos de Asturias, 1986.

Snoek, Jan A. M. y Henrik Bodgan. "The History of Freemasonry". En Handbook of Freemasonry. Editado por Herink Bodgan y Jan A. M. Snoek. Leiden: Brill, 2014.

Soto, Myrna. El arte maestra. Un tratado de pintura novohispano. México, CDMX: UNAM, Instituto de Investigaciones Bibliográfica, Consejo Nacional de Ciencia y Tecnología, 2005.

Terán Bonilla, José Antonio. "La formación del gremio de albañiles de la ciudad de Puebla, en el siglo XVI y sus ordenanzas”. Cuadernos Arquitectura Docencia 11 (1993).

Vázquez Semadeni, María Eugenia. "La imagen pública de la masonería en Nueva España, 1761-1821”. Relaciones XXXII, no. 125 (2011 [citado el 30 de noviembre de 2015]): disponible en http://www.revistarelaciones.com/files/revistas/125/pdf/07mariaEugeniaVazquez.pd f

Vorágine, Santiago de la. La leyenda dorada. Madrid: Alianza Forma, 2008.

Ventura Lara, Libny Rodrigo. "El templo de Colohete (Honduras) y su significado simbólico". REHMLAC 6, no. 1 (mayo-noviembre 2014 [citado el 30 de noviembre de 2015]): disponible en http://revistas.ucr.ac.cr/index.php/rehmlac/article/view/15228/14527

Yung, John K. y Barb Karg. El gran libro de la masonería,. Traducción de Lilia Guerrero. Bogotá: Panamericana Editorial, 2011. 